NBER WORKING PAPER SERIES

\title{
WHY IS MANHATTAN SO EXPENSIVE? \\ REGULATION AND THE RISE IN HOUSE PRICES
}

\author{
Edward L. Glaeser \\ Joseph Gyourko \\ Raven Saks
}

Working Paper 10124

http://www.nber.org/papers/w10124

\author{
NATIONAL BUREAU OF ECONOMIC RESEARCH \\ 1050 Massachusetts Avenue \\ Cambridge, MA 02138 \\ November 2003
}

We are grateful to The Manhattan Institute for supporting this research. Gyourko also thanks the Research Sponsors Program of the Zell/Lurie Real Estate Center at Wharton for funding. This paper has benefited from comments provided by Matt Kahn, Albert Saiz, Jesse Shapiro, and seminar participants at the Federal Reserve Bank of New York, the 2003 NBER Summer Institute, and the Wharton School of the University of Pennsylvania. The views expressed herein are those of the authors and not necessarily those of the National Bureau of Economic Research.

(C2003 by Benajmin M. Friedman. All rights reserved. Short sections of text, not to exceed two paragraphs, may be quoted without explicit permission provided that full credit, including $@$ notice, is given to the source. 
Why is Manhattan So Expensive? Regulation and the Rise in House Prices

Edward L. Glaeser, Joseph Gyourko, and Raven Saks

NBER Working Paper No. 10124

November 2003

JEL No. R0

\begin{abstract}
$\underline{\text { ABSTRACT }}$
In Manhattan and elsewhere, housing prices have soared over the 1990s. Rising incomes, lower interest rates, and other factors can explain the demand side of this increase, but some sluggishness on the supply of apartment buildings also is needed to account for the high and rising prices. In a market dominated by high rises, the marginal cost of supplying more space is reflected in the cost of adding an extra floor to any new building. Home building is a highly competitive industry with almost no natural barriers to entry, yet prices in Manhattan currently appear to be more than twice their supply costs. We argue that land use restrictions are the natural explanation of this gap. We also present evidence consistent with our hypothesis that regulation is constraining the supply of housing so that increased demand leads to much higher prices, not many more units, in a number of other high price housing markets across the country.

Edward L. Glaeser

Department of Economics

Harvard University

Littauer Center

Cambridge, MA 02138

and NBER

egakleser@harvard.edu

Joseph Gyourko

Finance Department

The Wharton School

University of Pennsylvania

Philadelphia, PA 19104-6367

Raven Saks

Department of Economics

Harvard University

Littauer Center

Cambridge, MA 02138
\end{abstract}




\section{Introduction}

In some of America's great cities, residential real estate prices have soared over the past twenty years. In Boston and San Francisco, the median home price rose by 153 and 81 percent, respectively, in constant dollars between 1980 and 2000. According to the U.S. Census, the median value of an owner-occupied housing unit in Manhattan rose from $\$ 245,633$ in 1980 to $\$ 377,246$ in 2000 (both figures in 2002 dollars), implying an average annual compounded real appreciation rate of 2.2 percent, which is double the national average real appreciation rate on the widely-used Freddie Mac Repeat Sales Price Index. Rising incomes and declining interest rates almost certainly have increased the willingness to pay for proximity to productivity and amenities. The buoyant financial sector, which thrives on the information flows facilitated by New York's high density, has pushed New York's real per capita income from \$26,730 to \$46,349 between 1979 and 1999 (again both figures in 2002 dollars). ${ }^{1}$

New York's high wages and attractive amenities make the demand for its space understandable, but increases in the demand for housing need not always create such large price increases. In many places, the supply of housing seems almost perfectly elastic. For example, the population of Las Vegas almost tripled between 1980 and 2000, but the real median housing price did not change. In fact, real median housing prices fell in more than one-third of the larger American cities that added housing units at the national rate or faster since 1980. In the sprawling cities of the American heartland, land remains cheap, real construction costs are falling, and expanding supply keeps housing prices down.

Even in New York City, housing supply used to help keep prices down. As New York grew in earlier decades, existing blocks of apartments and homes were demolished to make way for denser residences. Figure 1, which plots data back to the 1950s, shows that

\footnotetext{
${ }^{1}$ In 2002, 40 percent of the wage payroll in Manhattan was generated by the financial sector, broadly defined.
} 
such rapid price growth has not always been the norm. ${ }^{2}$ During this earlier period, tens of thousands of new units were built in Manhattan, and prices stayed flat. There were 13,000 new units permitted in Manhattan in 1960 alone, versus only 21,000 new units permitted in Manhattan throughout the 1990s. Since 1980 and in spite of skyrocketing prices, the housing stock of each of the three cities noted above has grown by less than 10 percent.

In this paper, we try to make the case that the limited supply response is not the result of technological constraints, or imperfect competition in the construction industry, but rather the consequence of an increasingly restrictive regulatory environment. In Manhattan and in other parts of the country, local homeowners have become more and more competent in blocking new development which they presumably oppose because the new development would reduce the value of their property either because of increased supply or because of congestion-related externalities. For reasons discussed just below our focus is on New York City and Manhattan in particular, but we also present evidence for 21 major metropolitan areas across the country.

The prevailing methodology for assessing the impact of government regulation on housing price is to compare housing prices in places with some observable form of regulation with prices in places without that form of regulation. Katz and Rosen (1987) provided one of the very first and best known such estimates, concluding that house prices were from 20-40 percent higher in San Francisco area communities that had enacted growth moratoria or imposed growth management control plans in the $1980 \mathrm{~s}^{3}$ This work is compelling, but more widespread analysis of this type is very difficult to undertake because much regulation of the housing market is extremely challenging to quantify. The opponents of development have a strikingly diverse array of weapons,

\footnotetext{
${ }^{2}$ The price data plotted in Figure 1 are for the metropolitan area as a whole. See the notes to the figure for the details.

${ }^{3}$ Speyer (1989) and Pollakowski and Wachter (1990) followed with confirmation of significant capitalization in two other metropolitan areas. There is also an extensive literature on zoning that is related to our research, as one way to restrict development is via zoning. The interested reader should see Fischel (1985) for an excellent review of that area and Hamilton (1978) for an early empirical study linking zoning restrictions to high house prices.
} 
ranging from environmental law suits to public demonstrations which extend far from the official rules that are supposed to influence the amount of construction.

Consequently, we adopt a different approach that depends much more on basic economics. One of the strongest implications of free markets is that in an open, competitive, unregulated market, the price of a commodity will not be greater than the marginal cost of producing that good. Construction is an enormously competitive industry, with more than 130,000 establishments nationwide and more than 1,000 establishments in multifamily construction in New York State alone. Free competition among these suppliers should ensure that prices are pushed down to marginal cost, so the presence of a large gap between market values and marginal production costs indicates the presence of supply-side restrictions. ${ }^{4}$ If we are confident that we are not missing any technological barriers to construction, then the gap between market value and the cost of supply must reflect the impact of government regulation.

This approach has two obvious problems. First, our evidence is indirect, and we cannot measure the price impact of any specific policy. Different types of zoning restrictions or growth controls certainly could have different effects in the market. Second, unless we are confident that our cost numbers fully capture the marginal cost of housing and that the construction industry is perfectly competitive, our estimates will overestimate the impact of regulation either because of omitted costs or because we are mistaking monopoly power for government-created barriers to entry. We will address these concerns by providing auxiliary information on the impact of zoning and other supplyside restrictions and by interpreting only very large gaps between prices and production costs as evidence for government regulation.

This suggests that the key task in our approach is to estimate the marginal cost of producing a house. In the case of single-family homes, this combines the cost of building the structure and the cost of buying and preparing the land. In the case of multifamily 
apartments, the marginal cost of a unit is the cost of expanding a new project upwards. Land shortages well may limit certain types of development in Manhattan, but builders always can add an extra floor if that would be profitable. Thus, to understand the marginal physical cost of building a new apartment we do not need to consider land purchase or preparation costs, as these are fixed costs which do not influence the marginal cost of building up. This is the primary reason why we focus on Manhattan, as we are much more confident of the quality of the cost data in such a market.

Different data sources provide a range of estimates, from $\$ 120$ - $\$ 220$ per square foot, for the physical costs of different types of residential building construction in Manhattan. These figures are meant to capture the purely physical costs of construction and do not include the potentially very large costs associated with assembling a site for construction. Still, we believe that a figure from the upper end of this range is a reasonable estimate for providing more space if the builder were legally allowed to build up.

The data clearly show that market prices in Manhattan have been at least double this marginal cost of production for many years. In the most recent years, Manhattan condominiums have been selling for $\$ 600$ per square foot, which is triple the marginal cost of building up. This gap is so large that it is hard to believe that measurement error in building costs could be responsible for the difference in any meaningful way. ${ }^{5}$ If it costs $\$ 200$ per square foot to build an apartment that sells for $\$ 600$ per square foot, then this would seem to offer an irresistible arbitrage opportunity for developers. The best explanation for why they do not take advantage of this opportunity is the reason they tell us themselves: New York's maze of building regulations effectively cap their building heights.

To support our contention that the price/cost is the result of regulation, not some other force, we present other evidence on the New York housing market. First, we present a

\footnotetext{
${ }^{4}$ There are exceptions to this, of course, including the mark-ups that can occur when monopoly power is present. We discuss this issue more fully below where we show it is not relevant to the home building industry.
} 
brief synopsis of "The Battle of Carnegie Hill," a classic case where local homeowners used the regulatory process to halve the height of a new building. Second, we present data on permitting activity, which also supports our contention that changes in the regulatory environment help us to understand why Manhattan prices have skyrocketed.

We then ask whether other markets exhibit similarly large gaps between the price of housing and the marginal cost of producing that housing. Given the rise of the so-called Smart Growth movement in particular and environmental sensitivities more generally, providing a broader geographic perspective is a useful exercise. ${ }^{6}$ We report results for the 21 metropolitan areas tracked in the 1998-99 special Metropolitan files of the American Housing Survey (AHS). ${ }^{7}$ In twelve out of the twenty-one markets that we examine, the typical home costs no more than 110 percent of the combined costs of the physical structure and the land. However, in the Boston, New York City, Newport News, Salt Lake City and Washington, D.C. metropolitan areas, the gap between construction costs and home prices is between ten and thirty-three percent. In the Los Angeles, Oakland, San Francisco, and San Jose areas, the gap is from one-third to one-half of typical house value. Given that California is well-known as the epicenter of the restrictions on new construction, we found it gratifying that our measures suggested that California had the highest "regulatory tax."

Because the underlying data are for single family homes, we must estimate the price of land as part of the marginal cost of the housing unit. As we discuss later in the paper, there are a number of potential biases arising from the fact that there is insufficient data on existing land sales with which to estimate the cost of a standard unit of land in a straightforward manner. While the precise extent of bias is not known, we have made every attempt to be conservative in estimating the gap between house values and marginal production costs. While these results are inherently less robust than those we report for Manhattan because of the difficulties in estimating land price, the evidence still

\footnotetext{
${ }^{5}$ The unit prices are from actual sales so there is not even the normal worry about biases from selfreporting by owners for those data.

${ }^{6}$ The term Smart Growth typically refers to a variety of policies intended to deal with sprawl and other emerging points of debate and contention relating to the modern urban landscape.
} 
strongly suggests that prices exceed construction costs in many coastal housing markets, and by a fairly wide amount (if not by the precise numbers we report below in Table 6). To further investigate whether these measures reflect regulation or some other factor, we then correlate our regulatory tax estimates with other measures of zoning toughness. We find a significant positive correlation, indicating that places with larger gaps between market prices and production costs have more onerous zoning rules.

Finally, we ask whether the existing restrictions on new construction could be socially optimal. After all, since the value of owner-occupied housing used as primary residences is $\$ 9.4$ trillion according to the 1998 Survey of Consumer Finances, the social welfare losses due to inefficient regulation may be considerable. While welfare analyses of building restrictions are notoriously difficult to implement, the exercise is more straightforward in Manhattan because changes in density are unlikely to create large changes in the nature of the community. Our examination does not find any negative externality (or combination of externalities) even remotely large enough to warrant a development tax that leaves market prices as least double construction costs.

If we are right, and the building restrictions in New York have created this housing price boom, it is worth asking what the social losses are from these high prices. After all, the new residents are presumably being compensated for these high prices with higher wages and amenities. Old residents are benefiting from being able to sell their homes at extraordinary profits. If government regulation is excessive, the social losses are in the underpopulation of high productivity, high amenity places. In short, if our estimates are to be believed, then Manhattan is underpopulated. Likewise, high zoning taxes mean that many of the attractive areas in California have too few people relative to the social optimum. The social costs of binding development restrictions lie in the misallocation of consumers, and having them live in less productive, less attractive places.

The plan of the paper is as follows. The next section discusses the gap between housing prices and construction costs in Manhattan. Section III then presents other evidence on

\footnotetext{
${ }^{7}$ This work closely follows Glaeser and Gyourko (2002).
} 
regulation in the Manhattan market. This is followed in Section IV with the 21 metropolitan area analysis using the American Housing Survey. Section V describes our welfare analysis, and the paper concludes with a brief summary.

\section{The Gap Between Prices and Production Costs in New York}

Our primary empirical strategy is to measure the gap between real estate prices and housing production costs, and use that differential to measure the distortions in the housing market. ${ }^{8}$ We will use the term "Regulatory Tax" to reflect the increase in costs imposed by regulatory restrictions which themselves could include quantity controls, myriad zoning rules, or taxes and fees. As such, we will define the tax as:

(1) Regulatory Tax $=$ Market Price of a Housing Unit Marginal Cost of that Unit (absent government barriers)

This definition suggests two potential problems for accurate measurement. First, the marginal cost of a unit absent government barriers may be hard to measure. Second, even if we do measure this marginal cost correctly, there may be other reasons for a gap between price and marginal cost other than regulation (e.g., monopoly power of suppliers). A separate issue is if new construction generates negative externalities, then the optimal Regulatory Tax is positive. We will return to this point at the end of the paper, but at this point, we are trying to measure the regulatory tax, not inferring anything about its optimality.

The issues surrounding cost measurement are very different for single-family dwellings and large apartment buildings. In both cases, one component of cost is the physical cost of construction, and we can fairly accurately assess the physical costs of construction using sources such as the R.S. Means Company data. Their data include material costs

\footnotetext{
${ }^{8}$ Of course, as Glaeser and Gyourko (2003) emphasize, there is no reason why housing prices cannot fall below construction costs in declining areas. In those places, there will be no new building in the market.
} 
and labor costs, but not costs associated with land. ${ }^{9}$ For apartment buildings in which the marginal cost of a new housing unit is entirely reflected in the cost of building up (absent government intervention), we can readily estimate the marginal cost of the unit with construction cost data. In the case of single-family dwellings, we must also estimate the cost of land, also absent government intervention. Data on existing land sales with which to estimate land costs is very sparse, so we must use housing price hedonics to estimate the how much current homeowners "value" their own land. While we will turn to this approach for single-family homes in Section IV, the usual questions about hedonic estimates lead us to focus initially on multi-family dwellings which are free from this problem.

The second potential problem with our regulatory tax definition is that a gap between prices and costs can arise for reasons other than government regulation, particularly if some firms have market power that they can exploit. However, all available evidence suggests that the housing production industry is highly competitive, with no natural barriers to entry. The 1997 Economic Census reports that there were 138,850 establishments in the business of constructing single-family homes. While there are a huge number of small, 'mom and pop'-type operations, there also are more than 1,700 establishments with revenues in excess of $\$ 10$ million. The multifamily housing industry is only slightly less concentrated. In 1997, there were 7,544 establishments in this industry and more than 1,000 in New York state alone. In the absence of some type of land use controls, it is hard to doubt that residential construction would come as close as possible to the economic ideal of a perfectly competitive industry.

Given that Manhattan is an island, one is naturally tempted to wonder if a fundamental scarcity of buildable space has developed over time that, when coupled with strong recent demand, is responsible for today's high prices. However, even if vacant land is rare, new units could be supplied by 'building up'. Given the difficulties of accurately estimating the value of land, this makes Manhattan, a market dominated by multi-story residential

\footnotetext{
${ }^{9}$ Two publications are particularly relevant for greater detail on the underlying data: Residential Cost Data, $19^{\text {th }}$ annual edition, (2000) and Square Foot Costs, $21^{\text {st }}$ annual edition (2000), both published by the
} 
buildings, a natural application for our analysis. Because additional land is not required on the margin, the production costs of an extra housing unit in this market can be well approximated by the physical costs of adding an extra floor of space. As the appendix shows, much of the new construction in Manhattan in recent times has occurred at moderate building heights that could have easily been extended. Land shortages may limit certain types of development in Manhattan, but builders always can add one extra story if new housing units are needed.

Another potential source of distortions in the New York City housing market is rent control. ${ }^{10}$ In some cases, rent control may limit the ability to tear down existing renteroccupied buildings. Nonetheless, this should still reflect a fixed cost that does not change the marginal cost of constructing an extra apartment in a new development.

\section{Just How Expensive is Manhattan Real Estate?}

Our primary data on prices comes from condominium sales records in Manhattan from the First American Real Estate Corporation. These originate from deeds records and represent actual transactions prices over the period 1984 to 2002. All sales prices reported in this section are converted into 2002 dollars using the Consumer Price Index. And, as our construction cost data are generally on a per square foot basis, we will also convert our price data into per square foot measures.

We have a large sample of 23,060 condominiums spread throughout Manhattan. While there is considerable variation in the data, the basic numbers suggest that Manhattan

\footnotetext{
R.S. Means Company.

${ }^{10}$ Rent control is the most widely-studied housing regulation. The rent control literature is a lengthy one that has built on Friedman and Stigler's (1946) classic analysis (reprinted in Bloch and Olsen (1981)). De Salvo (1971) and Olsen (1972) produced the first modern, econometric analyses of New York City's control regime, with Rydell, et. al. studying Los Angeles' foray into controls. Linneman (1987) and Gyourko and Linneman $(1989,1990)$ followed with investigations of various equity and efficiency aspects of control regimes. This work continues with Moon and Stotsky (1993) using longitudinal data to estimate the impact of rent control on housing quality. Related work on how controls influence maintenance effort and long-term impacts of controls include Olsen (1988), Ault and Saba (1990), and Pollakowski (1999). Olsen and Early $(1998,2003)$ examine the relationship of rent controls with homelessness. More recently, Glaeser and Luttmer (2003) provide a new look at resource misallocation under controls. While most of
} 
condo units have been selling for around $\$ 460$ per square foot over the past two decades. Prices are generally high, and the small difference between the median value of $\$ 455$ per square foot and the mean value of $\$ 468$ per square foot indicates relatively little skewness in the distribution (see the top row of Table 1). While there is a considerable upper tail reflecting apartments that cost much more than $\$ 500$ per square foot, the high mean value is not being driven by a few outliers.

The variation in prices reflects both differences in the physical infrastructure of the apartments and the difference in neighborhood amenities. As our goal is to compare condominium prices with construction costs, we obviously are concerned about our inability to measure all aspects of physical apartment quality. However, unless neighborhood attributes specifically impact construction costs, the variation in prices that is related to neighborhood amenities will not bias our results. Indeed, in a truly free market, these amenities would not create a gap between construction costs and prices. More attractive neighborhoods would simply end up having taller buildings.

In the second and third rows of Table 1, we report data from the New York City Housing and Vacancy Survey (NYCHVS) for comparison purposes. Our NYCHVS sample combines all independent observations in Manhattan from the years 1991-1999. This widely-used data set has two failings relative to our condominium sales data. First, it is much smaller. We have only 156 observations of condominiums in Manhattan and 165 for the outer boroughs. Second, the price data relies on self-reported market values, not actual sales data. Even given these issues, the Manhattan data from the NYCHVS look remarkably similar to the condominium sales data. The mean price per square foot is $\$ 500$, which is only slightly higher than what actual transactions show (and which corresponds well with our priors and the literature on the upward bias of self-reported values). The median price per square foot is $\$ 461$, which is extremely close to the $\$ 455$ value that we observe in the condominium sales data. 
However, the data on condominiums in the outer boroughs suggest that the housing market outside of Manhattan is extremely different (row 3, Table 1). The mean price per square foot in the outer boroughs is $\$ 149 / \mathrm{ft}^{2}$, with the median value even lower at $\$ 120$. These results do not call into question the Manhattan data, but they do remind us that New York's hot housing market is a very localized phenomenon. The outer boroughs are still full of much less expensive housing.

In the remaining panels of Table 1, we examine prices by apartment size, building height, number of units in the building, and over time. Interestingly, there is little relationship between apartment size and value per square foot except among the largest apartments, which are more expensive. All else equal, larger apartments should be somewhat cheaper to build on a square foot basis because they have a fixed amount of some forms of infrastructure. Of course, all else is not equal and we believe these differences reflect omitted quality factors. The largest apartments almost certainly are nicer along other dimensions, so that it is likely that higher prices also reflect higher quality.

Not surprisingly, there is a tendency of prices to rise in value with building height. The average price per square foot for condos in buildings with between 10 and 20 stories is $\$ 400$, while the average price per square foot in buildings with more than 40 stories is $\$ 573$. These price differences presumably reflect two factors. First, apartments in taller buildings have better views. Second, taller buildings will tend to be more modern and perhaps be of higher quality.

We also see a pattern whereby prices are higher in larger buildings. The price per square foot is around $\$ 400$ in the smaller buildings (i.e., those with $<20$ units), but rises to over $\$ 500$ for units in large buildings (i.e., those with $>200$ units). Again, it is unclear if this price differential reflects better views or other characteristics that might be related to building size.

Finally, examining the data over time finds large increases in the price per square foot during the last few years. Prices were high in the 1980s and fell a bit during the recession 
in the 1990s. They then recovered, rising steadily in the second half of the 1990s and ending up at a level more than $\$ 100 / \mathrm{ft}^{2}$ above the previous high in the $1980 \mathrm{~s}$.

In Table 2, we look at the distribution of condominium prices by geographic location within Manhattan. Eighty-three percent of our sales occur in four neighborhoods that are closest to the midtown business district: the Upper East Side, the Upper West Side, Turtle Bay/Stuyvesant and Midtown. Approximately 10 percent of our sales also occur in the Greenwich Village/Financial District neighborhood. Less than five percent of the sales occur in the Lower East Side, Harlem, Morningside Heights and Washington Heights.

The most expensive area in the data set is the Midtown area where prices per square foot averaged $\$ 515$, with the median unit selling for $\$ 490 / \mathrm{ft}^{2}$. The Upper East Side was the next most expensive area with a mean price of $\$ 509 / \mathrm{ft}^{2}$. The Upper West Side was only slightly less costly with a mean value per square foot of $\$ 494$. Stuyvesant/Turtle Bay had the biggest representation in our sample, with over 6,000 units. The mean price in that neighborhood was $\$ 436$ per square foot. Units in the financial district and Greenwich Village were somewhat cheaper with an average cost per square foot of $\$ 416$. The Lower East Side apartments were cheaper still, valued at an average of \$373 dollars per square foot, which is still expensive but almost one-third cheaper than the top price neighborhoods.

The remaining three neighborhoods, Morningside Heights, Washington Heights and Harlem, appear to be quite different. In these neighborhoods, prices were generally below $\$ 250 / \mathrm{ft}^{2}$, and often well below $\$ 200 / \mathrm{ft}^{2}$. Indeed, values in these neighborhoods look more like the outer boroughs than the rest of Manhattan.

This neighborhood level evidence suggests that there is variation in prices across Manhattan, with the uptown areas being considerably cheaper. Nonetheless, there is a fair amount of uniformity across large parts of the borough. Prices are regularly above $\$ 400$ per square foot and, in many neighborhoods, almost one-half of the apartments cost more than $\$ 500 / \mathrm{ft}^{2}$. 
Within the owner-occupied sector, we have focused on condominiums rather than cooperative units because we are concerned that sales prices of cooperatives may not reflect the true cost of ownership due to their more complex ownership structures and allegedly high maintenance fees. Nevertheless, they do represent a significant fraction of the borough's housing stock so they clearly warrant study despite concerns about data quality.

Information on the distribution of self-reported market value per square foot using Manhattan coops in the NYCHVS is reported in Table 3. The mean value is $\$ 382 / \mathrm{ft}^{2}$, with the median sale price being $\$ 310 / \mathrm{ft}^{2}$. Holding unit and building quality constant, we would expect the absence of a straightforward, fee simple ownership status to result in lower values for cooperatives because property rights are valuable. Furthermore, the average reported monthly fee associated with these coops is $\$ 600 /$ month, which is about \$200 more than the average reported for condominiums in our sample, and at least partially reflects the fact that coop buildings have independent debt. ${ }^{11}$ Even with our concerns that reported values for cooperatives do not fully reflect the cost of owning the unit, these results clearly indicate that high prices are pervasive throughout the owneroccupied sector of the Manhattan real estate sales market, and are not confined solely to condominiums.

\section{The Costs of Production}

We now turn to our data on the costs of production. Our primary source for construction cost data is the R. S. Means Company, which surveys developers throughout the United States. Given that no data source is perfect, we supplement the information from Means with three other sources. One is Marshall \& Swift, a rival construction cost service. Second, we use estimates from the New York University (NYU) Center for Real Estate and Urban Policy. The ultimate source of their data is Zaxon, a third construction cost 
service. Finally, we use data on condominium costs outside of New York City using the American Housing Survey. It should be emphasized that in this section of the paper, the construction cost data pertain to condominium or cooperative-type product in multiple unit buildings (i.e., these are different from the single-family cost data discussed in Section IV).

The top panel of Table 4 reports construction costs for residential buildings by height that are specifically adjusted for the geographic area of Manhattan by the R.S. Means Company. Consistent cost data are available for structures of less than 25 stories. Physical construction costs range from $\$ 140-\$ 160$ per square foot for structures up to 24 stories tall. Taller buildings are modestly more expensive to build, although the Means data indicate that marginal costs are constant within a wide range of heights above seven stories. $^{12}$ If we interpret the Means data as applying to buildings shorter than 30 stories, these estimates apply to 88 percent of the buildings in our condominium sample. The NYCHVS topcodes building height at 20 stories, with 80 percent of the observations in multifamily structures within Manhattan having fewer stories. Thus, the vast majority of Manhattan residences are in a building type that is comparable with the Means cost estimates, and it appears that the marginal cost of increasing the height of a typical residential structure is about $\$ 160 / \mathrm{ft}^{2}{ }^{13}$

As an initial check on the reliability of these data, we turn to a separate set of estimates provided by the Marshall \& Swift Company (see the next panel in Table 4). These costs

\footnotetext{
${ }^{11}$ Thus, the fee differentials are not due entirely to different maintenance levels or requirements. See Schill, Voicu, and Miller (2003) for a recent analysis of the factors behind the pricing differences between condominium and cooperative units in Manhattan.

${ }^{12}$ It is not clear from these data whether costs per square foot are higher or lower for taller buildings. The Means Company notes that larger buildings tend to have lower costs per square foot, primarily due to economies of scale and the decreasing contribution of the exterior walls. However, it is possible that buildings much taller than 24 stories could have higher costs since they may require stronger structural reinforcements and higher quality materials.

${ }^{13}$ One can obtain a slightly higher marginal cost by making different assumptions regarding the underlying cost function. For example, if we were to begin by assuming the average costs reported by Means pertain to the $2^{\text {nd }}, 5^{\text {th }}$, and $15^{\text {th }}$ floors (i.e., to the midpoints of the three height categories), and then presumed that the average cost function is quadratic and goes through those midpoints (i.e., $\$ 142,2 ; \$ 144,5 ; \$ 160,15$ ), the total and marginal cost functions can be derived. In this particular example, marginal costs rise from around $\$ 140 / \mathrm{ft}^{2}$ on the lower floors to about $\$ 180 / \mathrm{ft}^{2}$ for floors $10-15$. To be conservative in our calculations below, we will use a value of $\$ 200 / \mathrm{ft}^{2}$ for construction costs in the analysis below.
} 
also are specific to Manhattan, but this firm provides a bit more detail with respect to the different qualities of residential buildings. Overall, these estimates span the results from the R.S. Means Company. Costs for an average or good quality apartment building are about $\$ 50$ per square foot less than the costs reported by Means; costs for what is termed an average quality, luxury apartment are about the same as Means reports; and costs for a high quality, luxury apartment are about $\$ 50$ per square foot higher than Means calculates. Using this data, the maximum construction cost per square foot is about $\$ 220$ per square foot for a very high-end residential building in Manhattan.

Yet another source of construction costs comes from a report prepared by Salama, Schill and Stark for the NYU Center for Real Estate and Urban Policy in 1999. They report evidence from Zaxon Inc., another construction cost estimator. These estimates, adjusted to 2002 dollars, indicate a construction cost of about $\$ 193$ dollars per square foot for a 15 -story apartment building, and $\$ 134$ per square foot for a six-story building. These data are very much in line with the Means numbers, although the marginal cost for an extra floor appears to be somewhat higher in these data. In addition, the NYU numbers are slightly below the cost of a high quality unit according to Marshall \& Swift. ${ }^{14}$

Our final piece of evidence on construction costs relies on condominium prices from the American Housing Survey for areas outside of New York City. As long as the property market has not been trending downward (which is the case for most of the 1990s), sales prices should represent an upper bound on construction costs because developers also need to turn a profit. ${ }^{15}$ The AHS data for Chicago indicate that the average price per square foot of condominiums is $\$ 144 / \mathrm{ft}^{2}$. In buildings with more than 10 stories, the price per square foot is $\$ 148$. In the rest of the United States, the price per square foot of

\footnotetext{
${ }^{14}$ As a point of reference, physical construction costs above $\$ 150 / \mathrm{ft}^{2}$ are at least as high as those pertaining to the highest quality single-family residences. In its single family construction cost files, the Means Company estimates that a large 2,200 square foot, custom quality home with an unfinished basement would have cost about $\$ 132 / \mathrm{ft}^{2}$ to build in the New York metropolitan area. The analogous figure for a luxury quality home, which is the highest quality category in the Means data, is $\$ 159 / \mathrm{ft}^{2}$. [No land costs are included in these figures.]

${ }^{15}$ There are too few observations on units in newly constructed buildings to create statistically meaningful samples.
} 
condominiums equals $\$ 129$. This estimate rises to $\$ 176 / \mathrm{ft}^{2}$ if we look only at buildings with more than 10 stories.

Although part of the price differential across locations may be attributable to differences in construction costs, the R.S. Means data suggest that the difference in construction costs across metropolitan areas is relatively small. For example, Means estimates that construction costs are 19 percent higher in the New York area than in Chicago. As such, 1.19 times sales prices in Chicago represents yet another estimate of construction costs in New York. Of course, to the extent that there might be a "regulatory tax" in other areas as well, this method will overstate construction costs. Taken together, these data strongly suggest that something near $\$ 200 / \mathrm{ft}^{2}$ is a reliable upper bound on the marginal cost of 'building up' for the vast majority of Manhattan apartments. ${ }^{16}$

\section{The Regulatory Tax in Manhattan}

In computing the regulatory tax as the difference between marginal production costs and market price, we will use $\$ 200$ per square foot as our estimate of the former. We recognize that there will be a small number of apartments that actually cost more than this amount to build, but in most cases this value will overstate, not understate, the true cost. When combined with the fact that reported asset values of older units are not adjusted for depreciation, these assumptions make it highly likely that our estimate of the regulatory tax will be a lower bound. ${ }^{17}$

\footnotetext{
${ }^{16}$ As another source, we also turned to data from the New York City permit office. This office reports an estimate of the total value of structures put in place by builders along with the total number of units. Dividing the value per unit by the average square footage per unit from our condominium data yielded an average cost of $\$ 89 / \mathrm{ft}^{2}$. While this price is not totally implausible, especially if many of the units were somehow controlled or stabilized, it seems quite low. One explanation for this low value is that builders must pay taxes based on the value of construction they report. Therefore, they have an incentive to underestimate true construction costs. In any event, we take the permit data as further confirmation of our view that $\$ 200$ per square foot is a reasonably generous estimate of the marginal cost of building higher for high quality apartment buildings in Manhattan.

${ }^{17}$ Stated differently, none of the prices reported in Tables 1-3 reflect values 'as if new'. Ideally, these prices should be adjusted (upward) to account for the depreciation that occurs on older units before any comparison with replacement costs. Unfortunately, the condo sales data from the First American Real Estate Corporation do not include any information on the age of the buildings in which the units are situated. The NYCHVS does report age in discrete form, including the following five categories: (a) built in the 1990s; (b) built in the 1980s; (c) built between 1960-1979; (d) built between 1930-1959; and (e)
} 
Figure 2 begins the comparison by plotting the distribution of price-to-marginal cost ratios for condominiums in Manhattan. Note that very few units have ratios below one. In fact, price is above marginal production costs for 93 percent of the sample, with nearly two-thirds (63 percent) being worth more than twice marginal costs. For an overwhelming majority of Manhattan condominium owners, this suggests that some form(s) of regulatory constraint has meant that their cost of housing is more than double what it would be under a free development policy. Figure 3 charts the same information for our smaller sample of cooperative units. Nearly three-quarters of these units have price-to-marginal cost ratios above one, and one-third of this group is valued at more than double marginal construction costs. Thus, it is clear that the regulatory tax is meaningfully positive for this segment of the housing stock in Manhattan as well. ${ }^{18}$

For the median Manhattan condominium in our sample, the regulatory tax amounts to well over half of the total price of the unit. ${ }^{19}$ Even for a condo from the $25^{\text {th }}$ percentile of the price distribution, the tax makes up just over 40 percent of the $\$ 339 / \mathrm{ft}^{2}$ total cost. For cooperative units, the measured tax is smaller on average, but still is economically significant. It is $\$ 182 / \mathrm{ft}^{2}$ at the mean, which amounts to 48 percent of average coop value

built prior to 1930. To try to estimate the impact of depreciation on older structures, we regressed reported condo value in the NYCHVS on a set of age dummies to determine the average impact of age on value. Adjusting the reported prices to reflect the regression estimates of depreciation yielded a mean of $\$ 625 / \mathrm{ft}^{2}$ and a median of $\$ 601 / \mathrm{ft}^{2}$ for the 156 Manhattan condominiums in the NYCHVS, which is 20-25 percent higher than the reported values. However, the $\mathrm{R}^{2}$ from the regression was only 0.04 , not all the coefficients were statistically significant, and it was not the case that average values were monotonically lower the older the structure. Similar analyses with the cooperative unit observations for Manhattan from the NYCHVS yielded slightly higher upward adjustments (in percentage terms). However, these regression results also were somewhat imprecise. Given these uncertainties, we decided not to work with adjusted (i.e., higher) prices. While 'as if new' prices must be higher than the values we use, this decision is a conservative one in the sense that it guards against any upward bias in our estimates of the impact of regulatory constraints in the housing market.

${ }^{18}$ Our longer working paper version includes plots for the distribution of price-to-construction costs for rental units. While those results are less reliable because we must impute asset values for rental units (which is why do not report them here), it is noteworthy that for free-market apartments, 78 percent of the units are valued above construction costs. Despite the fact that rent stabilized apartments are much cheaper, it still is the case that 40 percent of them have implied asset values in excess of construction costs. This result is particularly striking given that our estimate of construction costs is almost surely an overestimate for older, lower quality buildings.

${ }^{19}$ From the top row of Table 1, we know that the median condominium price is $\$ 455 / \mathrm{ft}^{2}$. Assuming $\$ 200 / \mathrm{ft}^{2}$ in construction costs, the implied tax is $\$ 255 / \mathrm{ft}^{2}$. The ratio of $255 / 455$ equals 56 percent. 
in Manhattan. Thus, some type of regulatory constraints in the housing market appears to be responsible for at least 50 percent of overall unit value for the mean owned apartment.

Translating these figures into annual cost terms can help illuminate the economic relevance of these results. For simplicity, we presume the annualized cost can be approximated by the multiple of the real cost of capital (or the real interest rate) and the component of housing prices that we estimate to be the result of regulation. ${ }^{20}$ While real rates of interest currently appear to be quite high by some calculations ${ }^{21}$, we use a more conservative estimate of 3 percent for the real cost of capital to current borrowers. The top panel of Table 5 reports the distribution of the annual regulatory costs for owners in our condominium sample. For half of the sample, this estimate of the annual flow cost of regulation exceeds $\$ 5,500$ per year, or about 9 percent of mean annual wages in Manhattan. A quarter of the sample is paying at least $\$ 9,668$ per year, with the mean flow value of the tax being $\$ 7,382$. At a more detailed level, the value of the tax appears to lie between $\$ 5,000$ and $\$ 10,000$ per year for 31 percent of our sample. For another 12 percent, the burden lies between $\$ 10,000$ and $\$ 15,000$ per year. Yet another 8 percent of the sample pays between $\$ 15,000$ and $\$ 25,000$ per year. Finally, 3 percent of the sample has a tax amount that is greater than $\$ 25,000$ per year. ${ }^{22}$

\section{Other Evidence on the Regulatory Causes of New York's High Prices}

\footnotetext{
${ }^{20}$ A more sophisticated analysis might compute the user cost of owning (e.g., see Poterba (1984) for example). This term includes factors such as local property taxes and maintenance expenses (along with a liquidity premium possibly) that also are thought to influence the cost of owning. For simplicity alone, we assume these costs are orthogonal to the regulatory tax and exclude them from our analysis. To the extent they are positively correlated, our annual estimates are lower bounds.

${ }^{21}$ As we write, the current interest rate on 30-year, fixed rate mortgages is approximately 5.6 percent (depending upon factors such as points paid and the like) while inflation over calendar year 2002 was only 1.4 percent according to the annual average personal consumption expenditures chain-price index published by the Bureau of the Economic Analysis. The simple difference between these two figures is 4.2 percent.

${ }^{22}$ These particular results are sensitive to the values of the real cost of capital and true construction costs used in the calculation. However, absent much higher construction costs (e.g., $\$ 100$ per square foot higher) or much lower real interest rates (e.g., Japanese levels of near zero), the annual cost to condominium owners is substantial. In addition, housing prices in part reflect expectations about future prices. If future prices are expected to rise dramatically, then this might explain some of the high prices in New York and would suggest that our simple calculation of multiplying the gap between housing prices and construction costs with the cost of capital overstates the true impact of regulatory constraints. Of course, if by chance,
} 
Section II has documented that housing prices in Manhattan are far above construction costs. While we have trouble thinking of a plausible alternative explanation other than restrictions on construction for this fact, we recognize that we are in some respects just naming a residual. As such, in this section, we offer two alternative pieces of evidence which we believe support our contention that the gap between prices and costs is caused by barriers to construction.

\section{The Battle of Carnegie Hill}

New York City has many examples of battles between developers and local residents, but the 'Battle of Carnegie Hill', as it was referred to by the local press, is among the most famous of these cases. ${ }^{23}$ This case from the Upper East Side of Manhattan became locally famous because it involved the actors Woody Allen, Kevin Kline, and Paul Newman, as well as some of New York City's financial elite, including Citigroup CEO Sanford Weill and the family of the prominent investment banker and former Clinton Administration Deputy Secretrary of the Treasury, Roger Altman.

The case itself appeared mundane at first, with Citigroup selling a corner site at $91^{\text {st }}$ and Madison Avenue on which it had built a one-story branch bank facility to a local developer. That firm, Tamarkin Architecture and Development, proposed a 17-story apartment building. Even though the builder had previously acquired the air rights necessary for such a tall structure on the site and there are other buildings at least 17 stories high within eyesight of $91^{\text {st }}$ and Madison ${ }^{24}$, the development was potentially

New York City apartment prices were expected to fall (a not totally implausible possibility) then our calculation understates the true effect.

${ }^{23}$ We are grateful to Matt Kahn for bringing this particular case to our attention. It was reported by the New York Times as it was playing out. For more recent descriptions and overviews of the entire battle between the developer and its opponents from various perspectives, the interested reader can see reports and commentary from the following three sources: (a) New York Magazine, available at http://www.newyorkmetro.com/nymetro/realestate/neighborhoods/features/4521/; (b) The City Review, available at http://www.thecityreview.com/carmad.htm; and (c) the article "Carnegie Hill: By the Content of Its Character" which was posted on the 'upper east side' section of an electronic guide to what is happening in Manhattan; more specifically, see the Upper East Side, Manhattan section of 'about.com' at the URL http://uppereastside.about.com/library/weekly/aa031200a.htm.

${ }^{24}$ See photographs in The City Review article cited in footnote 23 for these details. 
constrained by other facets of the local regulatory environment, most prominently those associated with landmarks preservation. ${ }^{25}$

In the first half of 2000, the local Landmarks Preservation Commission denied the developer's request to build a 17-story building after hearing from numerous individuals and groups that the structure would unjustly change the character of their neighborhood. For his part, Mr. Allen even produced a short video about Carnegie Hill, and New York Magazine reports that Mr. Kline quoted Richard II to the Landmarks Preservation Commission on the matter- "How sour sweet music is, when time is broke, and no proportion kept!’”.

Even before the Landmarks Preservation Commission stepped in, Mr. Weill faced social pressure from at least some of his friends to stop the proposed development. New York Magazine reports that Mr. Altman's wife, Jurate Kazickas, personally approached Mr. Weill and asked him to buy back the site from the local developer--to which Mr. Weill allegedly responded by asking why Ms. Kazickas did not buy it back herself. ${ }^{26}$ Presumably, a group including famous entertainers and investment bankers was not financially constrained from taking up Mr. Weill's suggestion and forming their own personal 'preservation trust', but found it cheaper to achieve much the same end by entangling the development in New York City's regulatory maze.

Approximately three years later, construction finally was begun on a scaled down, 9-story building that had been approved by the Landmarks Preservation Commission. The point of this example certainly is not to conduct research by anecdote, however entertaining it might be. That the regulatory process constrains the ability to 'build up' beyond this example is supported by cases notes in the news reports cited above, as well as by data

\footnotetext{
${ }^{25}$ Any development that is not what is termed 'as of right' must go through the Uniform Land Use Review Process (or ULURP) in New York City. The building code and broader regulatory environment that helps determine what is and is not 'as of right' is very voluminous. For more on that, see the report by Salaama, Schill, and Stark (1999) on the myriad of factors affecting the cost of housing construction in New York City. Their Section 4 on the land use review process, building codes, permit approval, and taxes and fees is the most relevant to our work.

${ }^{26}$ For the direct quotes and the entire interchange, see the first page of the article by Ralph Gardner, Jr. on the New York Magazine web site listed in footnote 23.
} 
we obtained on the distribution of the height of new condominium buildings constructed in Manhattan in the 1980s. ${ }^{27}$ For example, our sample contains eight structures that were erected between 1980 and 1989 in the Midtown section of Manhattan, with their heights ranging from 4 to 70 stories. In the Upper East Side (Carnegie Hill's neighborhood), there were seven condominium buildings put up during the same time period, and they ranged in height from 1 to 32 stories. The Appendix reports analogous data for other Manhattan neighborhoods. While we do not claim that all this heterogeneity is due to regulation, the data are abundantly clear that much new residential building has occurred at fairly low densities.

The Battle for Carnegie Hill also helps illustrate another very important lesson for our research - namely, that it is extremely difficult to accurately measure the degree of regulatory constraint facing housing development. It was not simply the presence of a complex local code and one public commission that influenced a developer's decision to bring new housing units to the market, but also the ability of well-funded opponents to use the regulatory process to substantially delay and change proposals. The inability to measure all this precisely suggests that traditional difference-in-difference methods may radically underestimate the true impact of regulation on housing prices (assuming the measurement error is classical in nature, of course).

\section{Permitting and Prices}

We now provide another source of data — on house price changes and housing permitsthat is consistent with our hypothesis on the connection between government regulation and high prices in Manhattan. In a free market, one would expect increases in housing prices to lead to more new construction, but this need not be the case in a regulated market where regulatory constraints of various types can choke off new supply. Figure 1 already suggests that there has been a marked drop off in permitting in Manhattan over the past two decades, a period over which real house prices rose in excess of 2 percent per annum. In order to look at the relationship between prices and quantities a bit more

\footnotetext{
${ }^{27}$ The data are from the First American Real Estate Corporation, the source of the price data used in
} 
closely, we regressed the number of permits issued in Manhattan in a given year on the change in prices during the previous year. ${ }^{28}$ Figure 4 then plots the data and the regression line for four different time periods dating back to 1955.

The 1955-1969 period was a time of relatively modest real price changes, but any meaningfully positive appreciation typically was associated with a high level of permitting activity the following year. A similar, but less strongly positive correlation is observed for the 1970s in the adjacent plot. The variability in real price changes was greater from 1970-1979, but the association of larger price appreciation with higher future permitting activity is still clearly evident. ${ }^{29}$ Were this pattern to hold during the 1980s and 1990s, it clearly would be at odds with our conclusions that this is a market in which regulation is constraining builders from bringing new units to market. However, the bottom two graphs in Figure 4 document that changes in prices are not correlated with future permitting activity in the 1980s and 1990s. ${ }^{30}$

Although these simple regression plots obviously do not concretely identify a supplydemand framework (something that is well outside the scope of this study), they do strongly suggest that the supply side of the housing market was able to respond much more flexibly to higher demand in earlier decades. We know from above that real income per capita skyrocketed in Manhattan during the 1980s and 1990s. Thus, an examination of changes in prices and quantities is consistent with rising housing demand that was not met by changes in supply. These conditions could easily have led to the present situation in Manhattan in which the market price of the typical unit is at least double its production cost.

\footnotetext{
Section II.

${ }^{28}$ We use lagged prices on the right-hand side on the assumption that it takes some time for developers to be able to respond to price changes, even in an unregulated market. The house price series is for the New York metropolitan area. See the notes to Figure 4 for the details. There is not an analogous price series for Manhattan proper (i.e., for New York County).

${ }^{29}$ Both of the regression-line slopes are significantly different from zero at the 95 percent confidence level. However, the estimation error is large enough that we cannot confidently conclude the slope is greater for the 1955-69 period. All regression results are available upon request.

${ }^{30}$ While both slopes are slightly negative, we cannot reject the null that each is zero.
} 


\section{Is There Evidence of a Regulatory Tax in Other Housing Markets?}

The housing price data used in this section come from the 21 metropolitan areas tracked in the 1998-99 special Metropolitan files of the AHS. We use observations on single unit residences that are owner occupied. ${ }^{31}$ Thus, the typical house in these samples is a single family, suburban unit. The AHS data include self-reported home values, lot size, and a number of other physical attributes of the housing unit including living area square footage. Because the AHS contains no information on building costs, we turn to the R.S. Means Company for data on that variable.

The Means data for single family homes contain information on four unit qualitieseconomy, average, custom, and luxury. ${ }^{32}$ The data are broken down further by the size of living area (ranging from $600 \mathrm{ft}^{2}$ to $3,200 \mathrm{ft}^{2}$ ), the number of stories in the unit, and a few

\footnotetext{
${ }^{31}$ Condominiums and cooperatives in buildings with multiple units are excluded from this particular analysis.

${ }^{32}$ Means does not produce true constant quality cost series, as the company relies on building code requirements to guide its cost estimation process. Since we will be working with data from two consecutive years in this section, economically significant code changes are unlikely. Nevertheless, these data have been criticized by Somerville (1999) for not reflecting actual builder experience or fully controlling for quality changes. While his attempt to develop a constant quality construction cost series via hedonic techniques certainly could be quite valuable for analysis over long time spans, we do not believe the results of that analysis warrant not using the Means data or making adjustments to it. Somerville's results are based on data from a single home builder operating in three markets (Baltimore, Cincinnati, and Houston) over a thirteen year period from 1979-1991, so it is not surprising that a single firm's experience does not match a market-wide average. Moreover, the sample size in Somerville (1999) works out to an average of just under 60 observations per market area per year. Given the very small number of subdivisions that must be involved, this only increases the chances of idiosyncratic factors driving the differences between his hedonic series and the Means data for his three markets. In addition, there is no indication that a standard confidence interval around his hedonic cost estimate would not encompass the Means series. [There is no direct evidence that it would, either. We cannot replicate his results without access to the confidential data supplied by his builder and the first-stage results. References to large standard errors on key year controls in his first-stage regression hint that the confidence interval could be relatively wide.]

Other factors also increase our confidence in the Means data. One is that it has passed a market test in the sense the firm has successfully sold its construction cost estimates for over 60 years. While we recognize the conceptual superiority of a true constant quality cost series, none has been developed yet that has passed such a test. Another is that the Means data have performed well in other contexts. Glaeser and Gyourko (2003) and Gyourko and Saiz (2003) have used the Means cost data in the construction of variables that work well (i.e., as the relevant theory would predicts) in regression analysis. While there is no doubt that Means measures construction costs with some error, we know of no reason to suspect a systematic bias. And, if the data largely reflected noise, then it is unlikely it would perform so well in the papers just cited. Finally, the cost estimates that Means produces for the Manhattan market are close to those we were able to gather from other independent sources for that market. We do not have independent sources for any of the other markets we study.
} 
other differentiators. In our comparisons with house prices from the metropolitan files of the AHS, we presume that construction costs are those associated with the mean of economy and average quality homes. Holding constant the size and other physical traits of the unit, construction costs for an average quality home are about 40 percent higher than those for an economy quality home according to the Means data. Thus, our estimates of construction cost reflect modest quality, but not the lowest possible quality that meets building code requirements. ${ }^{33}$

While there are various adjustments that need to be made to the data before comparing house prices to construction costs, the biggest difficulty with this procedure is in inferring the free market cost of land. ${ }^{34}$ As discussed above, we use the AHS data to estimate the marginal value of land via a standard housing hedonic that expresses the value of a house as a function of its various characteristics, including the amount of land on which it sits. The estimated coefficient on land area will reflect the degree to which the market valuation of a house increases with lot size. Of course, this estimate of the market valuation of land area may be biased, particularly if the amount of land is correlated with omitted housing characteristics. If houses on bigger lots tend to be of higher quality (in ways that we cannot explicitly control for), the resulting specification error will bias the

\footnotetext{
${ }^{33}$ This assumption of modest, but not really low, quality is also reflected in our assumptions that the costs are for a one-story house with an unfinished basement and the average costs associated with four possible types of siding and building frame. In addition, we develop cost estimates for small $\left(<1,500 \mathrm{ft}^{2}\right)$, medium $\left(1,550-1,850 \mathrm{ft}^{2}\right)$, and large $\left(>1,850 \mathrm{ft}^{2}\right)$ homes in terms of living area.

${ }^{34}$ Two adjustments are made to the $A H S$ data before comparing house prices to construction costs. These are to account for the depreciation that occurs on older homes and to account for the fact that research shows owners tend to overestimate the value of their homes. To account for the latter factor, we follow Goodman and Ittner (1992) and presume that owners typically overvalue their homes by 6 percent. Empirically, the more important adjustment takes into account the fact that the vast majority of homes are not new and have experienced real depreciation. Depreciation factors are estimated using the AHS as follows. First, house value per square foot (scaled down by the Goodman \& Ittner correction) in the relevant year is regressed on a series of age controls and metropolitan area dummies. The age data are in interval form so that we can tell if a house is from 0-5 years old, from 6-10 years old, from 11-25 years old, from 25-36 years old, and more than 45 years old. As expected, the coefficients on the age controls are each negative and represent the extent to which houses of different ages have depreciated in value on a per square foot basis. We then adjust the reported values to account for the estimated depreciation so as to compare the value of a unit as if it were new with its replacement cost. On average, this adjustment results in about a 40 percent higher asset value for comparison with new construction costs. See our 2002 working paper for more detail on this procedure.
} 
coefficient upwards. Conversely, omitted characteristics will bias the coefficient downwards if houses on bigger lots are built where land is cheap. ${ }^{35}$

\section{Hedonic estimates of the value of land per square foot (in 2000 dollars) for the 21} metropolitan areas surveyed in the two most recent waves of the metropolitan files of the AHS are reported in Table 6 (see column 3). ${ }^{36}$ The metropolitan area files provide a relatively large number of observations, thereby allowing us to estimate attribute prices fairly precisely, while covering a fairly wide cross section of places in the most recent survey years. ${ }^{37}$

\section{The results from column three of Table 6 indicate a wide range of prices across metropolitan areas, ranging from 13-15 cents per square foot in Birmingham and Houston to about $\$ 4$ per square foot in the Bay Area communities of San Francisco and San Jose.}

\footnotetext{
${ }^{35}$ While these are the most likely sources of bias, there probably are other factors making it difficult to pin down the value of a standard unit of land (e.g., differential option value across locations, etc.). Our strategy is to make every effort possible to guard against our Regulatory Tax estimates from being biased upward for the single family house markets in which we must estimate land value as part of the marginal cost of production. Toward that end, we restrict the underlying samples from the AHS to homes with no more than two acres of land (i.e., with less than 87,120 square feet of lot). Including observations with larger amounts of land reduces estimated land prices below those reported below in Table 6, suggesting that there is some downward bias of the hedonic estimates associated with large lot residences being developed in parts of the metropolitan area with cheap land. In addition, as suggested above, the hedonic estimate of land price will overestimate the free market value in markets with binding regulatory constraints.

${ }^{36}$ Four different hedonic specifications were estimated. Generally, the specifications are of the following form: House Price $=p^{*}$ Land Area $+z^{*}$ Other Controls, where the model is estimated separately for each metropolitan area. The other controls include the number of bedrooms, the number of bathrooms, the number of other rooms, an indicator variable that takes on a value of one if the home has a fireplace, an indicator variable that takes on a value of one if the home has a garage, an indicator variable that takes on a value of one if the home is in the central city of the metropolitan area, an indicator variable that takes on a value of one if the home has a basement, an indicator variable that takes on a value of one if the home has central air-conditioning, and the age of the home. Two of the specifications use the logged value of house price, while two are purely linear in nature. In addition, two of the models (one logged, the other not) use the data on interior square footage to capture the size of the home, while the other two use the detail on the number of bedrooms, bathrooms, and other rooms. In general, the results were quite consistent, although there is some variability in estimated land prices across the different hedonic models. The land prices in Table 6 are the mean of the values from the two specifications yielding the second and third highest prices (i.e., we rank the specifications from lowest to highest implicit land prices estimated and report the average of the prices from the second and third specifications). The key conclusions regarding the zoning tax are not sensitive to this choice. All the underlying results are available upon request.

${ }^{37}$ Our 2002 paper performed a similar analysis using the 1999 national file of the American Housing Survey. The results are similar quantitatively, with the coastal metropolitan areas having much higher marginal prices of land. However, the estimates here tend to be smaller and much more precisely estimated. Given the far fewer number of observations at the metropolitan area level in the national file, we are much more confident of the reliability of the results reported here.
} 
While there clearly are some high price places, these data suggest that consumers in most areas place a relatively low value on land on the margin. In 16 of the 21 metropolitan areas, the estimated price is below $\$ 1$ per square foot. In the two lowest price areas of Birmingham and Houston, the hedonic land values imply that a typical homeowner would be willing to pay no more than $\$ 1,400-\$ 1,600$ for an extra quarter acre of land. ${ }^{38}$ Even in the Baltimore and Salt Lake City metropolitan areas, in which we estimate the price of land to be from $\$ 0.83-\$ 0.88$ per square foot, a quarter acre of land is valued at no more than $\$ 9,040$. On the other hand, the hedonic price of land is much higher on the West Coast. Using the $\$ 4$ per square foot average of the prices in the two Bay Area metropolitan areas surveyed implies that a quarter acre is valued at well over $\$ 40,000$.

While these calculations obviously take some liberty with the meaning of a small change in the quantity of land, they do illustrate that the value of land as measured by these hedonic prices is not likely to constitute the bulk of the total value of the typical home in most of these metropolitan areas. This is evident by comparing the quarter acre land values discussed above with the mean home prices (in 2000 dollars) reported in column four of Table 6 .

The final column in Table 6 reports our estimate of the Regulatory Tax as a percentage of average house value in the metropolitan area. Note that the tax is zero or negligible (defined as less than 10 percent) in over half the markets. ${ }^{39}$ However, the tax exceeds 10 percent of average home price in nine market areas (Boston, Los Angeles, New York, Newport News, Oakland, Salt Lake City, San Francisco, San Jose, and Washington, DC). While the 12 percent figure for the New York metropolitan area is interesting for comparison purposes with the results we reported above for Manhattan condominiums, the impact of regulation on land values is much higher in other markets, especially those

\footnotetext{
${ }^{38}$ There are 43,560 square feet in an acre of land, so $\$ 0.13 * 10,890=\$ 1,416$ and $\$ 0.15 * 10,890=\$ 1,634$. ${ }^{39} \mathrm{We}$ assigned a value of zero for the Regulatory Tax if physical construction costs exceeded the average house price in the metropolitan area. We would not expect to see new construction in areas with production costs above market prices. In all areas but Philadelphia and Pittsburgh, a positive Regulatory Tax results if we assume construction costs associated with the lowest quality units (i.e., economy homes) tracked in the Means Company data. Effective house quality may, in fact, be lower than we presume in these areas, but we think it preferable to employ assumptions that lead our estimates to be conservative rather than aggressive.
} 
on the west coast. In Los Angeles, Oakland, San Francisco, and San Jose, the gap between prices on the extensive and intensive margins amounts to from one-third to onehalf of home value at the mean. In Boston, Newport News, and Washington, DC, the gap constitutes about one-fifth of total property value.

Thus, the evidence for single-family housing markets across a diverse set of metropolitan areas recently tracked by the American Housing Survey suggests a big role for regulatory restrictions in accounting for high house prices in a select set of primarily coastal markets. While we have taken every possible precaution to guard against our Regulatory Tax estimates from being biased upward, we fully recognize that the inability to fully control for heterogeneity in the quality of land makes these estimates less robust than those reported above for Manhattan.

Faith in the reliability of these regulatory tax estimates would be increased by showing that they are related to zoning or other land use restrictions. Unfortunately, such data are difficult to obtain. Perhaps the most prominent source of such information comes from the Wharton Land Use Control Survey. This survey took place in 1989 and covered 60 metropolitan areas. While this is a decade prior to our AHS-based results, if there is persistence in the strictness of land use controls over time ${ }^{40}$, then we still should see a meaningfully positive correlation between our Regulatory Tax measure and the severity of land use restrictions.

Among other variables in the Wharton Land Use Control Survey is a measure of the average length of time between an application for subdivision approval and the issuance building permits for a modest size, single family subdivision of less than 50 units, which we term SUBDIVTIME. This measure can take on values ranging from one to five with a value of one indicating the permit issuance lag is less than three months, a value of two indicating the time frame is between three and six months, a value of three indicating a 7-

\footnotetext{
${ }^{40}$ Housing industry professionals certainly claim there is, but there is no consistent time series evidence of which we are aware on this matter. This clearly is a matter that future research should address.
} 
12 month lag, a value of four meaning the lag is between one and two years, and a five signaling a very long lag of over two years.

We are able to match data for this variable with 20 of the 21 metropolitan areas reported in Table $6{ }^{41}$ The simple correlation between our regulatory tax measure and SUBDIVTIME is 0.74. Regressing our regulatory tax estimate on SUBDIVTIME finds that a unit increase in the categorical zoning lag variable is associated with a 15 percentage point increase in the amount of the regulatory tax. ${ }^{42}$ While this sample size is quite small and no causality can be inferred, it still is comforting that the places we estimate to have high regulatory tax levels are in fact those with more onerous zoning. ${ }^{43}$

\section{Can Manhattan's Regulatory Tax Be Justified?}

While our findings suggest that regulation has restricted supply in Manhattan and a few other coastal housing markets, the existence of such a gap between price and marginal cost is not necessarily inefficient. Indeed, much of the literature on zoning (see Fischel, 1985) has argued that land use controls are absolutely necessary to get developers to internalize the social costs of their actions. In this section, we ask whether there is likely to be any negative externality large enough to warrant a Regulatory Tax of the size we estimate exists for Manhattan.

\footnotetext{
${ }^{41}$ The Wharton Land Use Control Survey did not include the Norfolk-Newport News area.

${ }^{42}$ The $\mathrm{R}^{2}=0.55$ and the $\mathrm{t}$-statistic on the zoning constraint variable is 3.2 from this regression with 20 observations.

${ }^{43}$ Other measures in the data base include the analogue to this zoning delay question, except that the permit length time applies to a request for rezoning for residential building purposes in a small subdivision. Examination of this and other related variables found correlation patterns similar to those just reported. In our longer working paper version we also investigated the correlation between our regulatory tax variable and the time to permit issuance following zoning requests using data from the 1989 national file of the AHS. Two benefits of using that data are that the year is identical to that of the zoning survey and a few more metropolitan areas can be matched across the two data sources. The biggest drawback is that there are far fewer observations per metropolitan area, so that the underlying hedonic trait price estimation used to compute the price of land and, therefore, the regulatory tax amount, is much noisier. The correlation between the regulatory tax estimates and the zoning measure was smaller, but still significantly positive at 0.39 . And, the analogous regression still yields a significantly positive coefficient implying about a 7 percentage point increase in the regulatory tax amount for a unit increase in the categorical zoning regressor. See Table 6 to our 2002 working paper for those details.
} 
In Manhattan, an optimal zoning tax should incorporate at least three elements in order to reflect the marginal social cost of a new resident to the community. First, and most obviously, the zoning tax should reflect the fact that a new apartment may eliminate views of existing apartments. Indeed, most current height restrictions exist for exactly that reason. Second, the new development should be taxed to the extent there are negative externalities created by extra crowding. Pure wage effects (i.e., the fact that more workers can depress wages) are pecuniary, not real, externalities and the usual economic logic suggests that these effects should not be part of the development tax. Third, any tax should reflect the fiscal burden of the new resident. The fiscal burden should be defined as the difference between government expenditures on the new resident and the taxes that the resident will face. After addressing each component in turn, we conclude that the present degree of regulatory constraint on new housing construction is inefficiently higher — and most probably by a wide margin.

While welfare analyses of zoning are inherently difficult to perform, Manhattan provides perhaps the best possible laboratory. Adding even a large number of housing units and people will not change the basic nature of the place, a factor that makes the evaluation much more straightforward. That said, our results are most properly viewed as educated guesses, not precise estimates.

\section{Estimating the Value of Views Destroyed by New Construction}

The view-related externality is perhaps the most straightforward to estimate. For each new apartment, the view-related externality equals the number of views blocked by a new apartment times the welfare cost of blocking a view. The number of views blocked should reflect the marginal impact of a single new apartment given the existing structure of apartments in New York.

In a world with homogeneous consumers, the welfare value of a view should equal the current market price of a view, which can be estimated by comparing apartments with or 
without views. ${ }^{44}$ Benson, et. al. (1998) have recently reviewed the existing literature on hedonic estimates of the price of a view. Estimates vary, but a typical result suggests that a good view raises the value of the property by about 10 percent. However, most of this literature uses cross sectional data on single family homes and often estimates the value of a view associated with some type of natural resource such as the ocean or a mountain range. Hence, the relevance for our problem of the value of an urban view is somewhat limited.

Consequently, we decided to compare the prices of condominiums in the upper and lower floors of the same building using our sample of Manhattan condos, which covers 20,426 units in 518 apartment buildings. We regressed price (in log form) on the square footage of the unit (also in log form) and a series of dummy variables controlling for the floor of the unit and a measure of unit size. Specifically, we included a dummy variable $\left(\mathrm{I}_{11-20}\right)$ that takes on a value of one if the unit is on floors 11-20, another dummy variable $\left(\mathrm{I}_{21-30}\right)$ that equals one if the unit is on the $21^{\text {st }}-30^{\text {th }}$ floors, and yet another $\left(\mathrm{I}_{31+}\right)$ for units on or above the $31^{\text {st }}$ floor of their buildings. The regression results were as follows

$$
\begin{aligned}
\log (\text { Price })= & .08 \bullet \mathrm{I}_{11-20}+.16 \bullet \mathrm{I}_{21-30}+.23 \bullet \mathrm{I}_{30+}+1.00 \bullet \log (\text { Square Footage }) \\
(.006) & (.009)
\end{aligned}
$$

The regression also includes building-specific fixed effects and year-of-sale fixed effects that are not reported here. Standard errors are in parentheses and the $\mathrm{R}^{2}=0.59$.

We are most interested in the coefficient on the $\mathrm{I}_{31+}$ indicator variable that effectively captures the difference in the prices of condos on the bottom ten floors of the building relative to those above the $30^{\text {th }}$ floor. Fully recognizing that this coefficient of 0.23 is

\footnotetext{
${ }^{44}$ In principle, this will be true with heterogeneous consumers as well as long as there are enough apartments of differing types. If a new apartment blocks the view of someone who values his view more than the market does, this person can just move apartments and acquire a new (identical) apartment with a view paying the market cost of a view. Of course, we recognize that urban housing markets are rarely that fluid.
} 
likely to overstate the value of a view ${ }^{45}$, the results suggest that the difference in value between being really high up in a building and being on the first ten floors is about 25 percent of unit price, which we use as our estimate of the value of a view. ${ }^{46}$

How many apartments' views does a new apartment block? No economic literature on this topic exists. One should be an upper bound on this number. After all, the worst outcome possible is that no apartments have any views, and this would mean that on average each apartment blocks one other apartment's view. Of course, it is easy to contemplate lower numbers. For example, it is possible to imagine tall buildings spaced far enough from one another (perhaps in the Corbusier Radiant City) so that no views are blocked. We take 0.5 as a reasonable middle ground and we will use this value as our estimate.

Given the assumptions, each new apartment destroys one-half of a view of some other apartment. Since the loss of one complete view would reduce the value of the apartment by 25 percent, each extra dollar of tall building will lead to about 12.5 cents of lost view. This finding suggests that lost views are not likely to amount for more than 10-15 percent of the total value of new housing. As such, views alone suggest that apartments should face a construction related regulatory tax equal to approximately 12.5 percent of their value.

\section{Congestion Externalities}

A second possible source of externalities that could justify a large regulatory tax on development is crowding. If people find living in a crowded place distasteful or more costly, then it is sensible to tax new residents for the costs they impose on current

\footnotetext{
${ }^{45}$ Unit quality is not fully captured by controlling for unit size (and we do not have other variables in our data set). If interior quality is superior on higher floors, as we suspect is the case, our estimate of view is biased upward. We are largely unconcerned by this because our goal is not to provide a precise measure, but to determine whether views and other externalities could reasonably justify the gap between values and costs that we currently see in Manhattan. An overly generous estimate of the value of a view serves that purpose well.
} 
residents. This is a difficult issue to analyze for a number of reasons. First, there is research in urban and transportation economics which suggests that tall buildings actually help internalize congestion because trips can be shortened or the number reduced. ${ }^{47}$ If that effect is dominant, then building up should be subsidized, not taxed. A related question is whether the appropriate tax should be based on gross or net congestion. Gross congestion can be thought of as the social costs imposed on New Yorkers created by one more apartment in New York. Net congestion is the social costs imposed on New Yorkers by having one more apartment minus the social costs alleviated by having the apartment located somewhere else. Perhaps in an ideal system, all localities would charge fully for the gross congestion cost to that locality. However, if some localities are not charging (as Table 6 suggests is the case), then it seems like the appropriate tax should be based on net congestion costs.

Indeed, the net congestion cost imposed by an extra apartment in New York might be positive. Given New York's specialization in high density, we suspect that congestion externalities could be lower in Manhattan than anywhere else in the country. First, the island does not have a bucolic, rural character that would be spoiled by new residents. Second, residents of Manhattan overwhelmingly take public transportation or walk. Only 11 percent of Manhattan residents in the 2000 census reported driving alone or carpooling to work. Congestion does matter on the sidewalks or the subways, but it is far less important than when driving, mostly because people without cars take up so much less room than people with automobiles. Congestion also could be reduced if the number of overall trips is reduced by building to greater densities, per the discussion just above. If one accepts these arguments, then it seems quite likely that the relative congestion effect of moving to New York (versus whatever alternative locale) is likely to be negative. By turning a car driver into a subway rider, congestion on net is reduced rather than increased. Moreover, urban residents of Manhattan move there in part to be around other people. This reflects a congestion amenity, not a disamenity.

\footnotetext{
${ }^{46}$ Because the indicator variable is not continuous, the derivative relating price to floor is not well defined. Using the adjustment suggested by Halvorsen and Palmquist (1980) for such cases yields the 25 percent figure.

${ }^{47}$ See Fujita (1989) and Kanemoto (1980) for reviews and the theory behind this contention.
} 
While we suspect the net congestion externality may be positive, we do not try to estimate it, especially since it would be determined by the relevant alternative locale. Instead, we will attempt to estimate the size of gross congestion externalities, which should be thought of as the cash value of the total loss of utility on everyone in Manhattan created by a new resident. The natural means of estimating this value is to see whether rents, holding income constant, rise or fall with city population. If people demand a compensating wage differential for living in a more densely populated city, then a natural measure of urban amenities is the real income in the metropolitan area. In this case, income will be low in cities where amenities are high and high where amenities are low. As such, if the distaste for crowding is large, then we should expect to see a strong relationship between real income and city size.

Using the 193 cities in 1990 with population levels greater than 100,000, we estimate the following regression: ${ }^{48}$

(3) $\log ($ Median Rent $)=-3.4+1.04 * \log ($ Per Capita Income $)-.05 * \log ($ City Population $)$ (.64) (.06) $(.016)$

Standard errors are in parentheses, and the $\mathrm{R}^{2}=0.58 .^{49}$ The -0.05 coefficient on $\log$ population indicates that rents fall only modestly with increases in population, income held constant. The fact that a one percent increase in population causes a .05 percent decrease in rents suggests that people are paying less (holding income constant) in more populated places. This supports the idea that there is a small gross congestion externality. ${ }^{50}$

\footnotetext{
${ }^{48}$ This sort of specification will generate the elasticity that we are interested in if, for example, $\underline{U}=W / P+A$ across cities, where $\underline{U}$ is reservation utility, $\mathrm{W}$ is wages, $\mathrm{P}$ is the price level (which will be proxied for with rents) and A equals the amenity level.

${ }^{49}$ The regression also included a control for the percent of residents over the age of 25 with less than 9 years of schooling.

${ }^{50}$ That said, other specifications indicated a smaller negative or even positive effect of population. For example, controlling for land area turns the population coefficient positive, although not statistically significantly so. [The coefficient on land area is significantly negative, as expected.] We also tried controlling for density directly and found denser areas had higher prices. At face value, this suggests that crowding is good. However, this probably reflects omitted variables having to do with supply constraints
} 
While there certainly are reasons to question these estimates (e.g. the endogeneity of the variables discussed just above in footnote 50), they strike us as reasonable benchmarks for the value of the gross congestion externality in New York. Using this estimate, a one percent increase in city population reduces the utility level (measured as a share of housing costs) by one-twentieth of one percent. Another way to interpret this value is that with an extra percent of population in New York, the value of all homes will drop by one-twentieth of one percent due to congestion externalities. This argues for an additional five percent zoning tax on new apartments due to these congestion externalities. Thus, there appears no way that congestion externalities themselves could justify anything close to the size of the Regulatory Tax that we presently see in Manhattan.

Wage effects are even more problematic to estimate and interpret. As already noted, there are reasons to think that this impact should be ignored. If it is driven through standard labor market effects, then these are pecuniary rather than real externalities. And, in many cases, new apartments will lead to a redistribution of population from the suburbs to the central city and will not change the total size of New York's labor force.

The very direction of the impact of additional workers on wages in Manhattan is not at all clear. Although standard estimates in the labor economics literature find the slope of the demand curve to be steeply downward-sloping ${ }^{51}$, those results do not pertain to our analysis because they hold output and capital constant. In our case, it is not reasonable to assume that more workers simply would be dumped into Manhattan with no reallocation of capital or additional local output. ${ }^{52}$ Effectively, adding more people to the area will cause the demand for labor to shift out. Furthermore, urban agglomeration theory

or local amenities. In addition, attempts to instrument for population and density in the crowding regressions yielded slightly positive coefficients on population. In any event, all the analyses we have done indicates that -5 percent is an upper bound on this particular externality.

${ }^{51}$ In a comprehensive survey of the literature, Hamermesh (1993) concludes that the elasticity of employment with respect to wages lies in the range of -0.15 to -0.75 . These values imply an elastic response of wages with respect to employment.

${ }^{52}$ One would have to make an extreme assumption about the share of tradeable goods across areas to get no local output effects. 
suggests that productivity also may increase, with firms passing on some of the gains to workers. Thus, the diminishing marginal productivity of labor notwithstanding, wages might well rise with city population.

In fact, empirical work by Ciccone and Hall (1996) and Glaeser and Mare (2001) finds that increasing population levels are associated with increasing - not decreasing - wage rates when one looks at the relationship across cities. If agglomeration economies were dominant as these results indicate, then zoning restrictions would impose an additional cost in terms of limiting city size. Our experimentation with a number of models sometimes yielded a negative impact on wages, but it never was large (in absolute value) or statistically significant. ${ }^{53}$ In any event, even if this reflects a real, not a pecuniary, externality, its magnitude is far too small to rationalize development constraints that leave prices at least double production costs.

\section{Fiscal Externalities from New Construction}

The final category of social costs due to new construction that we examine comes through government taxation and expenditure. If new residents require far more in local government expenditures than they pay in taxes, then this would be yet another reason for potentially taxing new construction. Of course, one could argue that a sensible response to these fiscal externalities is just to charge new residents directly for the services that they use, instead of relying on some type of development tax. Still, it is worthwhile asking whether new residents in Manhattan condominiums even create a net fiscal drain on New York City.

While compelling statistics do not exist, there are a number of good reasons to believe that new residents in Manhattan condominiums would represent a considerable fiscal

\footnotetext{
${ }^{53}$ Empirical work in this area is fraught with various potential specification biases, so accurately pinning down an impact is very difficult. For example, regression estimates of the population-wages relationship using cross-sectional variation may be upwardly biased because more productive places (with higher incomes) end up attracting more people and, therefore, have larger populations. Regressions using changes in population and income may also be biased if increases in urban population are driven by increases to the productivity of the metropolitan area.
} 
transfer to, not from, the city. First, these residents tend to be rich. People living in apartments that cost more than $\$ 500,000$ will tend to be far richer than the average New Yorker. As such, they are likely to increase the average income in the city. Second, these residents tend to have small numbers of children. On average, 23 percent of the residents of Manhattan are enrolled in school, as opposed to 27 percent for the city as a whole. The residents of expensive condominiums are also disproportionately likely to have smaller families and to enroll their children in private schools. These individuals are paying taxes for the use of schools and not using them, to the benefit of the government's budget. Finally, a number of government expenditures entail large fixed costs. For these expenditures, new population is an unqualified improvement since it allows those expenditures to be spread over a larger base. Altogether, we are quite confident that the residents of new condominiums in Manhattan, even if those apartments were priced at $\$ 200 / \mathrm{ft}^{2}$ rather than $\$ 500 / \mathrm{ft}^{2}$, are likely to be a fiscal boon, not a fiscal drain on the city.

While the analysis in this section does not allow us to pin down the level of the optimal tax (or subsidy) on new development, it does show that there is no negative externality (or combination of externalities) remotely large enough to justify the current gap between prices and production costs of condominiums in Manhattan. Moreover, it is possible that a thorough analysis of the impact on transportation might even justify subsidizing denser construction in Manhattan. And, when one recalls that we have been very conservative in not adjusting market values for depreciation, thereby minimizing the measured gap between condominium values and their physical construction costs, it is hard to escape the conclusion that regulatory constraints on building in Manhattan are far too restrictive.

\section{Conclusion}

Home building is an enormously competitive industry with virtually no natural barriers to entry. Price markups over construction costs, therefore, are a strong indication of artificial barriers to new construction. In the bulk of the United States, the costs of producing housing are hard to estimate because of the lack of reliable data on the cost of 
land. Nevertheless, the data that are available indicate that in expensive coastal areas especially, there often is a substantial gap between the price of housing and construction costs. This gap suggests the power of land use controls in limiting new construction.

There is similar evidence of an important regulatory impact for Manhattan. Not only is this market interesting in its own right, but since the cost of building an apartment is always the cost of building up, construction costs for apartments are much easier to estimate. Because building up does not involve using more land, we can use the physical costs of construction to determine the costs of building an extra apartment without knowing the underlying cost of land. After examining several sources, we find that $\$ 200$ per square foot is about the maximum conceivable value of those construction costs in Manhattan. This level is high, but it is far below most condominium prices in Manhattan, which are now routinely two times that amount. As such, perhaps one half or more of the price of most condominiums in Manhattan can be thought of as the result of some type of regulatory constraint preventing the construction of new housing. Other evidence also supports the importance of regulation. For example, over the past 40 years in Manhattan, we have seen a substantial contraction in the number of residential building permits.

In principle, regulations limiting building need not be economically inefficient. However, we can find no externality associated with new housing units in Manhattan that is remotely large enough to warrant a development tax that is equal to construction costs themselves.

Why is the construction environment so restrictive and why has it become so much more restrictive over time? Our view is that there has been a re-allocation of property rights over the past 30 years. In the 1960s, land-owners were generally free to develop their property in the manner that they desired. However, starting in that decade and increasingly over the 1970s, 80s and 90s, neighbors have become increasingly effective in opposing new construction. As illustrated by the battle for Carnegie Hill, increasingly media-savvy local residents have become adept at using every means possible to restrict 
new construction. The result of this has been a reassignment of property rights from developers to local homeowners.

Of course, the Coase theorem tells us that this reassignment need not be inefficient. However, the reassignment of property rights appears to have resulted in rights that are both diffuse and poorly defined. The large amount of real estate litigation suggests that ownership is hard to clearly establish. Moreover, politics is frequently involved in property rights may be more closely linked to the ability to generate votes than any preordained legal right. These poorly defined, widely diffused property rights help us to understand why sensible mechanisms have not come about where developers efficiently compensate existing homeowners for any losses due to new construction. Furthermore, existing residents will always try to behave like monopolists, and will try to reduce supply to boost their own home values. ${ }^{54}$ Hopefully, future work will help us to understand why the impediments to new construction in Manhattan and certain other market have grown so much, and appear to be so high.

\footnotetext{
${ }^{54}$ Of course, this begs the question of why we do not see big gaps between price and marginal cost in all markets. Clearly, something else is influencing the propensity to act like monopolists. That is a subject for future research.
} 


\section{References}

Ault, R. and R. Saba, "The Economic Effects of Long-Term Rent Control: The Case of New York City", Journal of Real Estate Finance and Economics, Vol. 3 (1990): 2541.

Arnott, Richard. "Time for Revisionism on Rent Control?" Journal of Economic Perspectives, Vol. 9, no. 1 (1995): 99-120.

Benson, Earl, Julia Hansen, Arthur Schwartz, Jr., and Greg Smersh. "Pricing Residential Amenities: The Value of a View", Journal of Real Estate Finance and Economics, Vol. 16, no. 1 (1998): 55-73.

Ciccone, Antonio and Robert Hall. "Productivity and the Density of Economic Activity", American Economic Review, Vol. 6, no. 1 (1996): 54-70.

De Salvo, J.S. "Reforming Rent Controls in New York City: Analysis of Housing Expenditures and Market Rents", Regional Science Association Papers (1971): 195227.

Fischel, William. The Economics of Zoning Laws. Baltimore: Johns Hopkins University Press, 1985.

Friedman, Milton and George Stigler. "Roofs or Ceilings? The Current Housing Problem" (1946), reprinted in Rent Control, Myths and Realities: International Evidence on the Effects of Rent Control in Six Countries (W. Bloch and E. Olsen, eds.), Vancouver, BC: Simon Fraser Institute, 1981.

Fujita, Masa. Urban Economic Theory. Cambridge (UK): Cambridge University Press, 1989.

Glaeser, Edward and Joseph Gyourko. "The Impact of Zoning on Housing Affordability", NBER Working Paper No. 8835, March 2002.

Working Paper No. 8598 (revised version, 2003).

Glaeser, Edward, Joseph Gyourko, and Raven Saks, “Why Is Manhattan So Expensive?”, working paper, The Wharton School, University of Pennsylvania, May 2003.

Glaeser, Edward and David Mare. "Cities and Skills", Journal of Labor Economics, Vol. 19, no. 2 (2001): 316-342. 
Gyourko, Joseph and Peter Linneman. "Equity and Efficiency Aspects of Rent Control: An Empirical Study of New York City", Journal of Urban Economics, Vol. 26 (1989): 54-79.

. "Rent Controls and Rental Housing Quality: A Note on the Effects of New York City's Old Controls", Journal of Urban Economics, Vol. 27 (1990): 398-409.

Goodman, John C. and John B. Ittner. "The Accuracy of Home Owners' Estimates of House Value", Journal of Housing Economics, Vol. 2, no. 4 (1992): 339-357.

Hamilton, Bruce. "Zoning and the Exercise of Monopoly Power", Journal of Urban Economics, Vol. 5 (1978): 116-130.

Halvorsen, Robert and Raymond Palmquist. "The Interpretation of Dummy Variables in Semilogarithmic Equations", American Economic Review, Vol. 70 (June 1980): 47475.

Hamermesh, Daniel S. Labor Demand. Princeton: Princeton University Press, 1993.

Kanemoto, Yoshitsugu. Theories of Urban Externalities. Amsterdam: North-Holland Press, 1980.

Katz, Lawrence and Kenneth Rosen. "The Interjurisdictional Effects of Growth Controls on Housing Prices", Journal of Law \& Economics, Vol. 30, no. 1 (1987): 149-160.

Linneman, Peter. "The Effect of Rent Control on the Distribution of Income Among New York City Renters", Journal of Urban Economics, Vol. 22 (1987): 14-34.

Marshall \& Swift Valuation Service. Commercial Cost Explorer CD, January 2003.

Moon, C. and Janet Stotsky. "The Effect of Rent Control on Housing Quality Change: A Longitudinal Analysis", Journal of Political Economy, Vol. 101, no. 6 (1993): 11141148.

Olsen, Edgar. "An Econometric Analysis of Rent Control”, Journal of Political Economy, Vol. 80 (1972): 1081-1100.

. "What Do Economists Know About the Effects of Rent Control on Housing Maintenance?", Journal of Real Estate Finance and Economics, Vol. 1 (1988): 295-307.

Olsen, Edgar and Dirk Early. "Rent Control and Homelessness", Regional Science and Urban Economics, Vol. 28 (1998): 797-816. 
. "Subsidized Housing, Emergency Shelters, and

Homelessness: An Empirical Investigation Using Data from the 1990 Census", Contributions to Economic Analysis \& Policy, forthcoming 2003.

Pollakowski, Henry. "Rent Regulation and Housing Maintenance in New York City", MIT Center for Real Estate Working Paper \#79, 1999.

Pollakowski, Henry and Susan Wachter. "The Effects of Land-Use Constraints on Housing Prices", Land Economics, Vol 66, no. 3 (1990): 315-324.

Poterba, James. "Tax Subsidies to Owner-Occupied Housing: An Asset Value Approach", Quarterly Journal of Urban Economics, Vol. 99, no. 4 (1984): 729-752.

R. S. Means. Residential Cost Data, $19^{\text {th }}$ Annual Edition, R.S. Means Company, 2000.

Salama, Jerry, Michael Schill and Martha Stark. "Reducing the Cost of New Housing Construction in New York City". Working paper, The New York University School of Law, Center for Real Estate and Urban Policy, 1999.

Schill, Michael, Ioan Voicu, and Jonathan Miller. "The Condominium vs. Cooperative Puzzle: An Empirical Analysis of Housing in New York City", Working paper, The New York University School of Law, Center for Real Estate and Urban Policy, 2003.

U.S. Bureau of the Census. American Housing Survey, various National and Metropolitan Area Files, 1998-1999.

Wharton Land Use Control Survey. Prepared by Anita A. Summers and Peter Linneman. Philadelphia, PA: The Wharton School, University of Pennsylvania, 1989. 


\section{Appendix}

List of New Buildings by Height in Neighborhoods of Manhattan, 1980s

\begin{tabular}{|c|c|c|c|c|}
\hline $\begin{array}{l}\text { Greenwich } \\
\text { Village / } \\
\text { Financial } \\
\text { District }\end{array}$ & $\begin{array}{l}\text { Chelsea / } \\
\text { Clinton / } \\
\text { Midtown }\end{array}$ & $\begin{array}{l}\text { Stuyvesant } \\
\text { Town/ } \\
\text { Turtle Bay }\end{array}$ & $\begin{array}{l}\text { Upper West } \\
\text { Side }\end{array}$ & $\begin{array}{l}\text { Upper East } \\
\text { Side }\end{array}$ \\
\hline 6 & 4 & 5 & 4 & 1 \\
\hline 16 & 21 & 13 & 5 & 4 \\
\hline 18 & 30 & 21 & 9 & 5 \\
\hline \multirow[t]{8}{*}{44} & 35 & 24 & 11 & 12 \\
\hline & 42 & 27 & 31 & 14 \\
\hline & 53 & 29 & 35 & 15 \\
\hline & 56 & 30 & & 15 \\
\hline & 70 & 35 & & 18 \\
\hline & & 44 & & 19 \\
\hline & & & & 31 \\
\hline & & & & 32 \\
\hline
\end{tabular}

Source: Data from First American Real Estate Corporation. 
Table 1: Distribution of Price Per Square Foot for Condominiums

\begin{tabular}{|c|c|c|c|c|c|}
\hline & \# Obs. & Mean & $\begin{array}{c}25^{\text {th }} \\
\text { Percentile }\end{array}$ & Median & $\begin{array}{c}75^{\text {th }} \\
\text { Percentile }\end{array}$ \\
\hline Manhattan $^{1}$ & 23,060 & 468 & 339 & 455 & 572 \\
\hline Manhattan $^{2}$ & 156 & 500 & 271 & 461 & 664 \\
\hline Other Boroughs 2 & 165 & 149 & 89 & 120 & 177 \\
\hline \multicolumn{6}{|l|}{ By Unit Size $^{1}$} \\
\hline$\leq 600$ sq.ft. & 5,460 & 434 & 311 & 432 & 534 \\
\hline $600 \leq$ sq.ft. $\leq 800$ & 6,722 & 445 & 339 & 439 & 542 \\
\hline $800 \leq$ sq.ft. $\leq 1200$ & 6,729 & 472 & 346 & 460 & 580 \\
\hline $1200 \leq$ sq.ft. & 4,149 & 542 & 378 & 519 & 680 \\
\hline \multicolumn{6}{|l|}{ By Building Height $^{1}$} \\
\hline$\leq 10$ Stories & 3,686 & 377 & 252 & 365 & 474 \\
\hline $10<$ Stories $\leq 20$ & 5,760 & 400 & 269 & 385 & 500 \\
\hline $20<$ Stories $\leq 30$ & 3,199 & 497 & 396 & 482 & 577 \\
\hline $30<$ Stories $\leq 40$ & 5,227 & 498 & 384 & 489 & 589 \\
\hline $40<$ Stories & 4,788 & 573 & 438 & 543 & 678 \\
\hline \multicolumn{6}{|l|}{ By Building Size $^{1}$} \\
\hline$<20$ Units & 1,063 & 406 & 256 & 380 & 526 \\
\hline $20 \leq$ Units $<100$ & 5,548 & 415 & 285 & 398 & 513 \\
\hline $100 \leq$ Units $<200$ & 5,729 & 458 & 338 & 447 & 562 \\
\hline $200 \leq$ Units & 10,720 & 506 & 383 & 488 & 603 \\
\hline \multicolumn{6}{|l|}{ By Year ${ }^{1}$} \\
\hline 1984 & 700 & 373 & 221 & 359 & 488 \\
\hline 1985 & 982 & 451 & 305 & 450 & 550 \\
\hline 1986 & 1105 & 467 & 371 & 482 & 584 \\
\hline 1987 & 1616 & 507 & 420 & 505 & 591 \\
\hline 1988 & 2032 & 518 & 419 & 498 & 586 \\
\hline 1989 & 1535 & 515 & 391 & 484 & 586 \\
\hline 1990 & 911 & 443 & 340 & 434 & 516 \\
\hline 1991 & 722 & 421 & 310 & 383 & 499 \\
\hline 1992 & 755 & 363 & 273 & 343 & 426 \\
\hline 1993 & 41 & 385 & 284 & 379 & 463 \\
\hline 1994 & 87 & 369 & 279 & 341 & 431 \\
\hline 1995 & 232 & 354 & 267 & 342 & 408 \\
\hline 1996 & 1044 & 353 & 272 & 331 & 409 \\
\hline 1997 & 952 & 384 & 284 & 357 & 433 \\
\hline 1998 & 2114 & 410 & 315 & 392 & 476 \\
\hline 1999 & 2484 & 460 & 366 & 446 & 533 \\
\hline 2000 & 1873 & 557 & 451 & 553 & 652 \\
\hline 2001 & 1642 & 601 & 503 & 592 & 696 \\
\hline 2002 & 972 & 621 & 529 & 606 & 706 \\
\hline
\end{tabular}

1. Source: Condominium sales records from First American Real Estate Corporation. Nominal sales prices are converted to real 2002 dollars using the Consumer Price Index.

2. Source: New York City Housing and Vacancy Survey. Price is the reported market value for owneroccupied condos. Unit square feet is imputed from the number of rooms using the average square feet/room from condos in the New York MSA of the American Housing Survey. 
Table 2: Distribution of Price Per Square Foot by Geographic Area

\begin{tabular}{|c|c|c|c|c|c|c|}
\hline & \# Obs. & Mean & $\begin{array}{c}25^{\text {th }} \\
\text { Percentile }\end{array}$ & Median & $\begin{array}{c}75^{\text {th }} \\
\text { Percentile }\end{array}$ & $\begin{array}{l}\text { Average } \\
\text { Height }^{1}\end{array}$ \\
\hline \multicolumn{7}{|l|}{ NYC Condos } \\
\hline Manhattan & 23,060 & 468 & 339 & 455 & 572 & 27 \\
\hline \multicolumn{7}{|c|}{ By Neighborhood in Manhattan } \\
\hline $\begin{array}{l}\text { Greenwich Village/ } \\
\text { Financial District }\end{array}$ & 2,703 & 416 & 309 & 405 & 501 & 16 \\
\hline $\begin{array}{l}\text { Lower East Side / } \\
\text { Chinatown }\end{array}$ & 711 & 373 & 240 & 378 & 474 & 7 \\
\hline $\begin{array}{l}\text { Chelsea / Clinton / } \\
\text { Midtown }\end{array}$ & 4,086 & 515 & 355 & 490 & 648 & 34 \\
\hline $\begin{array}{l}\text { Stuyvesant Town/ } \\
\text { Turtle Bay }\end{array}$ & 6,534 & 436 & 330 & 443 & 539 & 31 \\
\hline Upper West Side & 3,913 & 494 & 361 & 476 & 592 & 24 \\
\hline Upper East Side & 4,759 & 509 & 372 & 490 & 611 & 29 \\
\hline $\begin{array}{l}\text { Morningside Heights / } \\
\text { Hamilton Heights }\end{array}$ & 18 & 162 & 130 & 141 & 190 & 5 \\
\hline Harlem & 131 & 277 & 191 & 245 & 371 & 6 \\
\hline $\begin{array}{l}\text { Washington Heights / } \\
\text { Inwood }\end{array}$ & 128 & 169 & 91 & 162 & 210 & 6 \\
\hline
\end{tabular}

Source: Condo sales records. All nominal values are converted to real 2002 dollars using the CPI.

1. Average number of stories. 
Table 3: Distribution of Cooperative Prices in Manhattan

\begin{tabular}{|c|c|c|c|c|c|}
\hline & \# Obs. & Mean & $\begin{array}{c}25^{\text {th }} \\
\text { Percentile }\end{array}$ & Median & $\begin{array}{c}75^{\text {th }} \\
\text { Percentile }\end{array}$ \\
\hline Owned Cooperatives \\
\hline Value per Square Foot & 794 & 382 & 176 & 310 & 501 \\
\hline
\end{tabular}

Source: New York City Housing and Vacancy Survey. 
Table 4: Construction Costs

\begin{tabular}{|c|c|}
\hline & Cost/sq.ft. \\
\hline \multicolumn{2}{|l|}{ RS Means: Apartments in New York City } \\
\hline $8-24$ story & 160 \\
\hline 4-7 story & 144 \\
\hline $1-3$ story & 142 \\
\hline \multicolumn{2}{|l|}{ Marshall \& Swift: Apartments in Manhattan } \\
\hline High-quality luxury apartments & 218 \\
\hline Average-quality luxury apartments & 156 \\
\hline Good-quality apartments, $3+$ stories & 123 \\
\hline Average-quality apartments, $3+$ stories & 96 \\
\hline \multicolumn{2}{|c|}{ NYU Center for Real Estate and Urban Policy ${ }^{2}$} \\
\hline 15 story luxury high-rise & 193 \\
\hline 6 story mid-rise & 134 \\
\hline \multicolumn{2}{|l|}{ AHS Condos in Apartment Buildings ${ }^{3}$} \\
\hline Chicago & 144 \\
\hline $10<$ Stories & 148 \\
\hline US excl. NY MSA & 129 \\
\hline $10<$ Stories & 176 \\
\hline
\end{tabular}

1. Costs per square foot are from the Marshall \& Swift Commercial Cost Estimator. Values are the average of reported costs for building classes A, B, C and D in November 2002.

2. Cost estimates are from Zaxon, Inc and converted to real 2002 dollars using the CPI.

3. Reported values are average price per square foot. Price is reported market value of owner-occupied units. Values are converted to real 2002 dollars using the CPI. 
Table 5: The Distribution of Estimated Zoning Taxes in Manhattan, Annual Flow Cost Estimates for Condominium Owners

\begin{tabular}{|l|l|l|r|r|c|}
\hline & \# Obs. & Mean & $\begin{array}{c}25^{\text {th }} \\
\text { Percentile }\end{array}$ & Median & $\begin{array}{c}75^{\text {th }} \\
\text { Percentile }\end{array}$ \\
\hline Manhattan Condos $^{1}$ & 23,060 & 7,382 & 2,927 & 5,554 & 9,668 \\
\hline
\end{tabular}

1. Source: Condo sales data from First American Real Estate Corporation. The zoning tax is calculated as the cost of capital times the difference between the sales price of a unit and estimated construction costs, where the cost of capital equals .03 and constructions costs equal $\$ 200 /$ square foot times the size of each unit. 
Table 6: Hedonic Land Prices and Zoning Taxes, Select Metropolitan Areas from American Housing Survey Metropolitan Files

$\begin{array}{ccccc}\text { Metropolitan Area } & \text { Year } & \begin{array}{c}\text { Hedonic Price } \\ \text { of Land } \\ \text { (\$lsquare foot) }\end{array} & \begin{array}{c}\text { Average } \\ \text { House } \\ \text { Value }\end{array} & \begin{array}{c}\text { Zoning } \\ \text { Tax/House } \\ \text { Value }\end{array} \\ \begin{array}{c}\text { Baltimore } \\ \text { Birmingham }\end{array} & 1998 & \$ 0.88 & \$ 154,143 & 0.018 \\ \text { Boston } & 1998 & \$ 0.13 & \$ 114,492 & 0 \\ \text { Chicago } & 1998 & \$ 0.68 & \$ 236,231 & 0.186 \\ \text { Cincinnati } & 1999 & \$ 1.62 & \$ 187,669 & 0.057 \\ \text { Detroit } & 1999 & \$ 0.40 & \$ 133,050 & 0 \\ \text { Houston } & 1998 & \$ 0.37 & \$ 144,686 & 0 \\ \text { Los Angeles } & 1999 & \$ 2.59 & \$ 103,505 & 0 \\ \text { Minneapolis } & 1998 & \$ 0.38 & \$ 144,719 & 0.339 \\ \text { New York } & 1999 & \$ 1.38 & \$ 253,232 & 0 \\ \text { Newport News (VA) } & 1998 & \$ 0.48 & \$ 127,475 & 0.122 \\ \text { Oakland } & 1998 & \$ 2.34 & \$ 284,443 & 0.321 \\ \text { Philadelphia } & 1999 & \$ 0.81 & \$ 135,862 & 0 \\ \text { Pittsburgh } & 1998 & \$ 0.70 & \$ 100,060 & 0 \\ \text { Providence } & 1998 & \$ 0.56 & \$ 148,059 & 0 \\ \text { Rochester } & 1998 & \$ 0.21 & \$ 109,050 & 0 \\ \text { Salt Lake City } & 1998 & \$ 0.83 & \$ 167,541 & 0.119 \\ \text { San Francisco } & 1998 & \$ 4.10 & \$ 418,890 & 0.531 \\ \text { San Jose } & 1998 & \$ 3.92 & \$ 385,021 & 0.469 \\ \text { Tampa } & 1998 & \$ 0.37 & \$ 103,962 & 0 \\ \text { Washington, DC } & 1998 & \$ 0.64 & \$ 213,281 & 0.219\end{array}$

Notes:

1.Hedonic prices of land were estimated using data from 1998 and 1999 metropolitan area surveys of the American Housing Survey. In some cases, areas were over sampled and included in the 1999 national file of the AHS. Four hedonic models were estimated. See the text and footnote 12 for those details. The prices reported here reflect the average of the prices associated with the second and third highest estimates across all four specifications (i.e., we discarded the highest and the lowest estimates and report the mean of the two remaining estimates).

2.The house price for each metropolitan area is the mean for the sample of single-unit homes with lot sizes less than two acres.

3.The computation of the zoning tax as a fraction of mean house value is as follows for each area $\mathrm{j}$ :

$\frac{\text { ZoningTax }_{j}}{\text { MeanHouseValue }_{j}}=\frac{\left(\frac{\text { MeanHouseValue }_{j}-\text { CC }_{j}}{\text { MeanLotSize }_{j}}-\text { HedonicLand PricePerSqft }_{j}\right) * \text { MeanLotSize }_{j}}{\text { MeanHouseValue }_{j}}$

Mean House Value and Mean Lot Size are metropolitan area-specific and pertain to the sample of single-unit, owner-occupied residences with less than two acres of land. See the first note for more on the hedonic price of land. 


\section{Figure 1: Housing Permits in Manhattan and Prices}

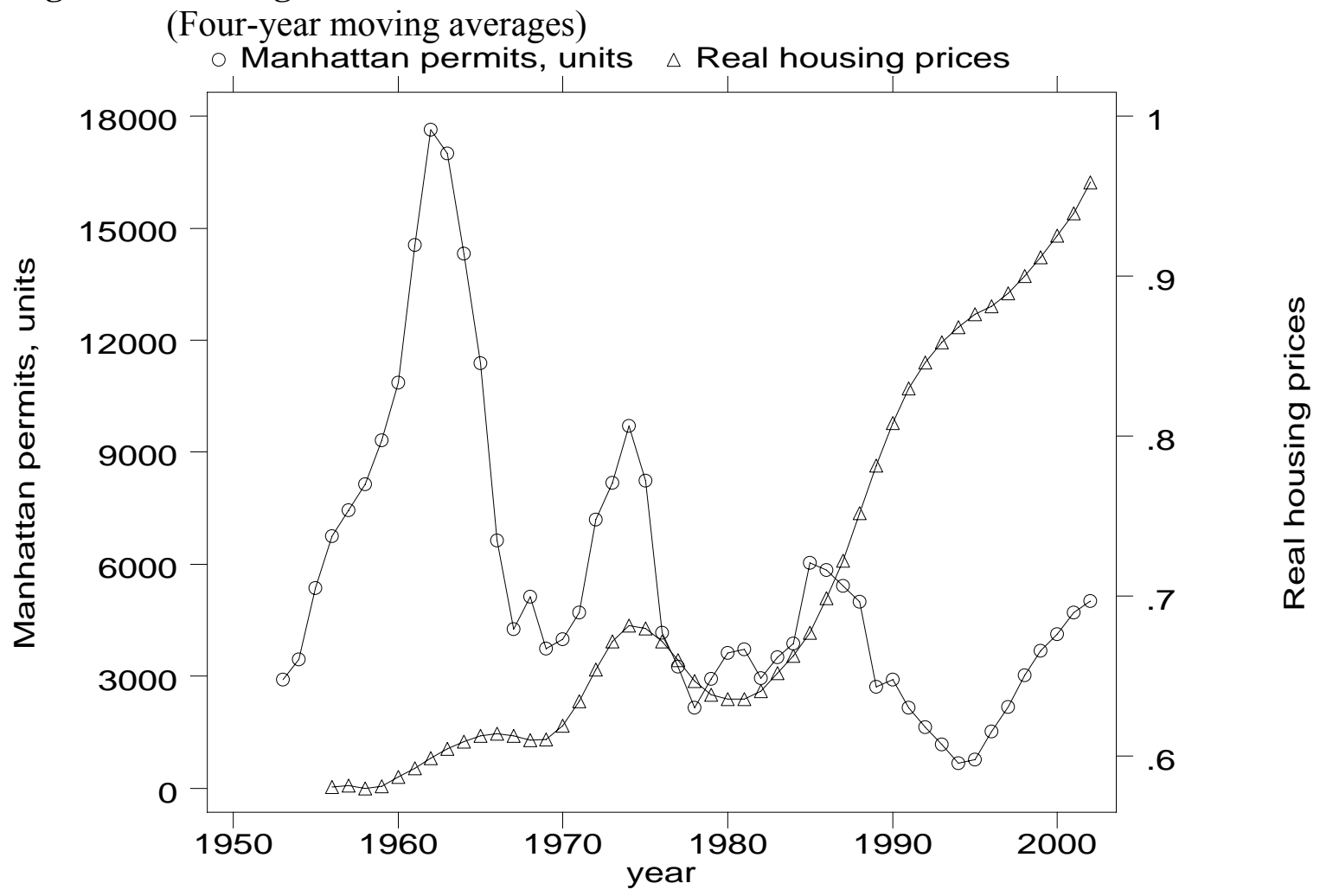

Source: Building permits are combined single- and multi-family permits for Manhattan from the US Department of Commerce. Real housing price series is the NY-NJ-LI MSA Consumer Price Index for Shelter, deflated by the GDP deflator from the National Income and Product Accounts and rescaled to equal 1 in 2002. 
Figure 2: Distribution of Price-to-Cost Ratio, Manhattan Condominiums

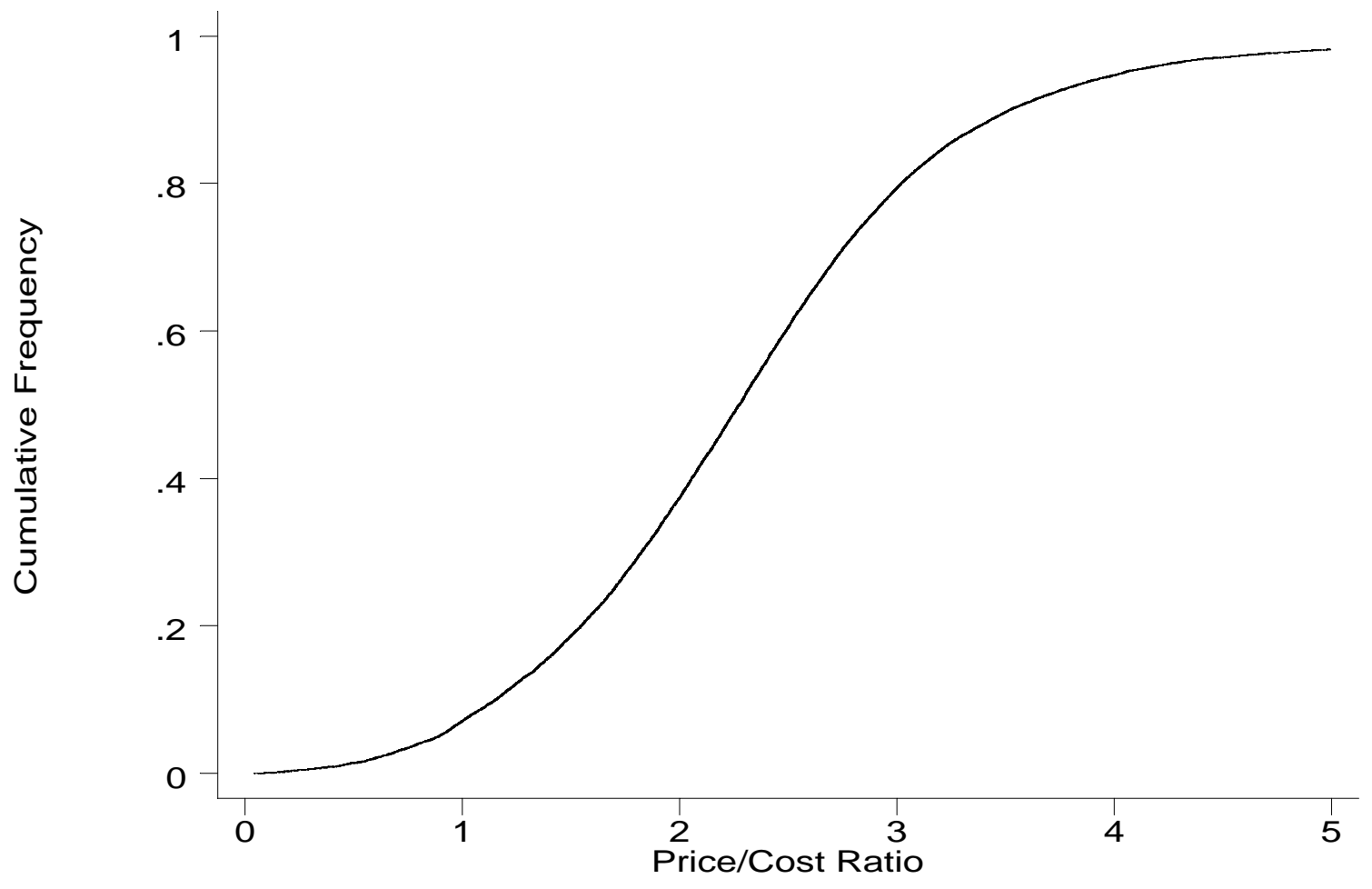

Source: Prices are from condo sales records and costs are \$200 per square foot. 
Figure 3: Cumulative Distribution of Price/Cost Ratio for Coops in Manhattan

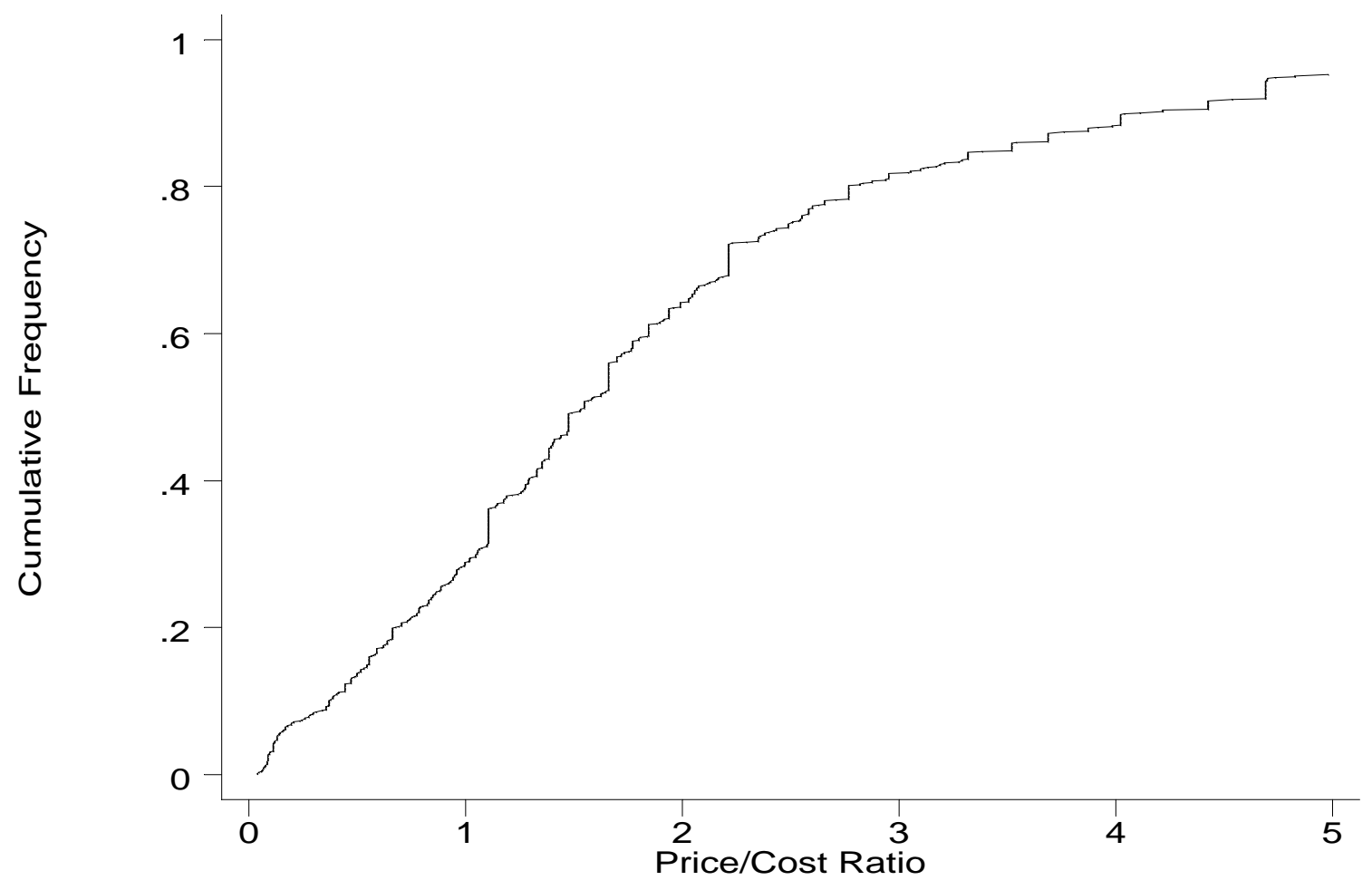


Figure 4: Changes in Manhattan Permits and (Lagged) House Prices, by Decade
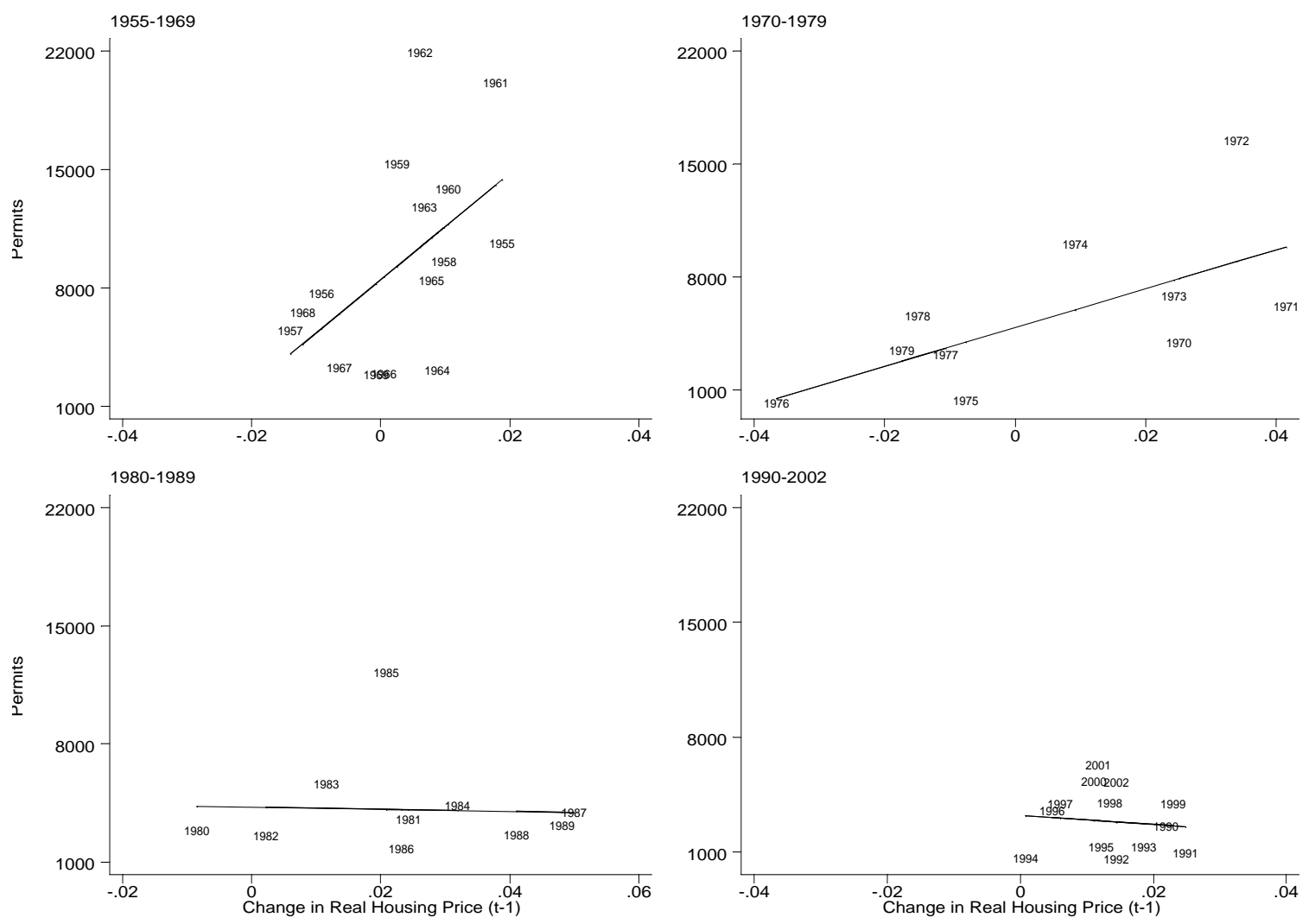

Source: Building permits are combined single- and multi-family permits for Manhattan from the US Department of Commerce. Real housing price series is the NY-NJ-LI MSA Consumer Price Index for Shelter, deflated by the GDP deflator from the National Income and Product Accounts and rescaled to equal 1 in 2002. 